\title{
Use of a Secretion Trap Screen in Pepper Following Phytophthora capsici Infection Reveals Novel Functions of Secreted Plant Proteins in Modulating Cell Death
}

\author{
Seon-In Yeom, ${ }^{1}$ Hyang-Ku Baek, ${ }^{1}$ Sang-Keun Oh, ${ }^{1}$ Won-Hee Kang, ${ }^{1}$ Sang Jik Lee, ${ }^{2}$ Je Min Lee, ${ }^{1}$ \\ Eunyoung Seo, ${ }^{1}$ Jocelyn K. C. Rose, ${ }^{2}$ Byung-Dong Kim, ${ }^{1}$ and Doil Choi ${ }^{1}$ \\ ${ }^{1}$ Department of Plant Science, Plant Genomics and Breeding Institute, Seoul National University, Seoul, 151-921, Republic \\ of Korea; ${ }^{2}$ Department of Plant Biology, Cornell University, Ithaca, NY 14853, U.S.A.
}

Submitted 11 August 2010. Accepted 22 January 2011.

In plants, the primary defense against pathogens is mostly inducible and associated with cell wall modification and defense-related gene expression, including many secreted proteins. To study the role of secreted proteins, a yeastbased signal-sequence trap screening was conducted with the RNA from Phytophthora capsici-inoculated root of Capsicum annuum 'Criollo de Morelos 334' (CM334). In total, 101 Capsicum annuum secretome $(\mathrm{CaS})$ clones were isolated and identified, of which 92 were predicted to have a secretory signal sequence at their $\mathrm{N}$-terminus. To identify differences in expressed $\mathrm{CaS}$ genes between resistant and susceptible cultivars of pepper, reverse Northern blots and real-time reverse-transcription polymerase chain reaction were performed with RNA samples isolated at different time points following $P$. capsici inoculation. In an attempt to assign biological functions to $\mathrm{CaS}$ genes, we performed in planta knock-down assays using the Tobacco rattle virusbased gene-silencing method. Silencing of eight CaS genes in pepper resulted in suppression of the cell death induced by the non-host bacterial pathogen (Pseudomonas syringae pv. tomato T1). Three CaS genes induced phenotypic abnormalities in silenced plants and one, CaS259 (PR4-l), caused both cell death suppression and perturbed phenotypes. These results provide evidence that the $\mathrm{CaS}$ genes may play important roles in pathogen defense as well as developmental processes.

In plants, one of the fiercest battlefields of plant-microbe interactions is the apoplastic milieu, which includes the cell wall matrix and associated extracellular environment (Hugot et al. 2004; Schulze-Lefert 2004). Here, secreted protein populations, or "secretomes", play a crucial role in the numerous complex defense responses that are mounted against pathogens, (Birch et al. 2006; Kamoun 2006; Lee et al. 2004, 2006a). During early stages of pathogen infection, plants recognize a patho-

Current address for J. M. Lee: Boyce Thompson Institute for Plant Research, Ithaca, NY 14853, U.S.A.

Corresponding author: D. Choi; Telephone: +1 82-2-880-4568; Fax: +1 822-873-2056; E-mail: doil@ snu.ac.kr

* The $\boldsymbol{e}$-Xtra logo stands for "electronic extra" and indicates that six supplementary figures and three supplementary tables are published online. Also, Figures 1, 2, and 6 appear in color online. gen-secreted elicitor, triggering defense responses through signaling pathways. Secreted proteins are known to be associated with cell wall thickening, to resist penetration, through cell polarization and papilla formation at the site of pathogen attack (Schmelzer 2002; Schulze-Lefert 2004). Secreted proteins, such as the classically defined pathogenesis-related (PR) proteins, contribute to the establishment of resistance and systemic acquired resistance in plants (Jones and Takemoto 2004; Stinzi et al. 1993; Wang et al. 2005).

The oomycete Phytophthora capsici is a soilborne pathogen of critical food crops, causing root and fruit rot of pepper, tomato, and other solanaceous or cucurbitaceous plants (Hausbeck and Lamour 2004; Walker and Bosland 1999). Recently, the incidence and infection of $P$. capsici has increased, leading to severe economic losses for these crops worldwide (Ristaino and Johnston 1999). To date, no useful management methods have been developed, because chemical and biological controls are limited and ineffective in preventing the spread of $P$. capsici to pepper crops (Oelke et al. 2003). Although many studies have reported that the resistance to $P$. capsici is polygenic and is controlled by quantitative trait loci (Kim et al. 2008; Lefebvre and Palloix 1996; Thabuis et al. 2003), little is known about pepper-oomycete interactions at the molecular and genetic levels. Furthermore, most genetic and molecular studies have focused on $P$. infestans - and $P$. sojae-host interactions (Birch et al. 2006; Kamoun 2006; Moy et al. 2004; Tyler 2007).

The defense response in plants is associated with a change in the repertoire of secreted proteins in response to Phytophthora spp. infection (Hugot et al. 2004; Lee et al. 2006a; Mithofer et al. 2002). The pepper-P. capsici interaction in resistant plants also occurs as an intercellular rather than intracellular response. For example, growth of $P$. capsici in resistant pepper is restricted to the extracellular environment through cell wall apposition related to secreted proteins; therefore, host cells are not severely damaged. In contrast, in susceptible pepper, $P$. capsici shows rapid intra- and intercellular growth, cell walls are degraded, and cells became plasmolyzed (Hwang et al. 1989; Ilarslan et al. 1996; Lee et al. 2000). A better understanding of defense mechanisms and, in this case, extracellular mechanisms may provide new insights into the interactions between $P$. capsici and pepper.

Because of the importance of secretory proteins, many researchers have developed high-throughput screening methods for their detection (Cutler et al. 2000; Jacobs et al. 1997; Tashiro et al. 1993). Among these, a yeast-based secretion trap 
(YST), using invertase as the reporter gene, has been successfully used for screening the plant secretome (Goo et al. 1999; Klein et al. 1996; Jacobs et al. 1997; Yamane et al. 2005) and for mining secretory proteins related to host-pathogen interactions (Hugot et al. 2004; Lee et al. 2006a; Oh et al. 2005). This technique involves ligating a plant-derived cDNA library into a YST vector fused to the invertase gene (Suc2) lacking the $\mathrm{N}$ terminal signal peptide. The heterologous cDNA library is transformed into an invertase-deficient yeast mutant. Any yeast transfected with cDNA encoding a secreted protein could secrete an invertase-fused protein, resulting in growth on medium containing sucrose as a sole carbon source. Rescued mutant yeast transformants are isolated and the genes encoding the secreted proteins can then be identified.

The purpose of this study was to characterize secreted proteins related to the defense response from a pathogen-resistant cultivar of pepper following inoculation with $P$. capsici. We isolated 101 Capsicum annuum genes encoding secreted proteins using the YST screen and compared the transcript levels in resistant and susceptible pepper cultivars at different time points following $P$. capsici infection. In addition, Tobacco rattle virus (TRV)-based gene silencing assays were performed to help determine the role of the secreted proteins in plant defense and development. Our study will facilitate a better understanding of the molecular functions of those secreted proteins that modulate the host defense response in plants.

\section{RESULTS}

\section{Confirmation of compatible and incompatible interactions} of pepper against $P$. capsici.

To better understand the spectrum of extracellular defense responses against pathogen attack, we attempted to isolate genes encoding secreted proteins modulated during cell death due to infection by an oomycete pathogen. Specifically, we inoculated the roots of $C$. annuum 'Criollo de Morelos 334' (CM334) and 'Chilsungcho', which are cultivars that are resistant and susceptible, respectively, to $P$. capsici, with $P$. capsici zoospores. Disease symptoms (root rot) were observed in Chilsungcho but not in CM334 within $72 \mathrm{~h}$ postinoculation (hpi) (Fig. 1A). To validate these symptoms, we performed a 2,3,5triphenyltetrazolium chloride (TTC) reduction assay as a cell vitality indicator (Chen et al. 2006). Although no differences were observed above ground during infection until $72 \mathrm{hpi}$, the vitality of $P$. capsici-infected roots changed dramatically between the two pepper cultivars (Fig. 1B). Differences in TTC reductase activity in the root of both cultivars were observed at 3 hpi but were significant from 24 to $48 \mathrm{hpi}$, showing two or three times more activity in CM334 than in Chilsungcho.

We also determined biomass of $P$. capsici hyphae in the infected pepper roots and the expression of $\mathrm{PR}$ proteins as positive markers for $P$. capsici infection (Silvar et al. 2008). During infection, transcript levels of the $P$. capsici elongation factor $1 \alpha(P C E F 1 \alpha)$ gene were significantly lower in roots of CM334 than in those of Chilsungcho (Fig. 1C). CaPINII and CaBPRl transcripts were more strongly and rapidly induced in the resistant than the susceptible cultivar (Fig. 1D), confirming that the two cultivars exhibit compatible and incompatible interactions, respectively, with $P$. capsici (Hwang et al. 1989; Ueeda et al. 2006). Root samples were harvested at various time points after inoculation of $P$. capsici and total RNA extracts were isolated for further study.

\section{Isolation of $C$. annuum secretome using YST.}

To understand the extracellular events during the defense response, a cDNA library was constructed in pYST $0-2$ vector (Lee et al. 2006a,b) using pools of mRNA (3, 6, 12, 24, 48, and
72 hpi) from CM334 pepper roots infected with $P$. capsici. An invertase-deficient yeast strain (DBY $\alpha 2445)$ was transformed with the pepper cDNA library constructed in pYST $0-2$ vector and plasmid DNA was isolated from all colonies that grew on yeast-peptone-sucrose (YP-Suc) media. To avoid selection of overlapping clones, the cDNAs selected through the first screen were then used to identify redundant clones by Southern blot analysis using amplified inserts as probes, in an iterative step. In total, 600 yeast transformants were selected from the YST screen and we identified 101 unique Capsicum annuum secretome $(\mathrm{CaS})$ genes, which we used for further study (Table 1).

The CaS cDNAs were sequenced and the deduced amino acid sequences were analyzed with the SignalP 3.0 (Bendtsen et al. 2004), TargetP (Emanuelsson et al. 2007), and PSORT programs (Nakai and Kanehisa 1992) to confirm the presence of secretory signal peptide and to predict subcellular localization, respectively. Of these, $92 \mathrm{CaS}$ clones were predicted to encode proteins with signal peptides or signal anchors that indicate targeting to the secretory pathway or apoplast by at least one prediction program. The other nine $\mathrm{CaS}$ clones were predicted to encode proteins with no signal sequence or to localize to microbodies, the cytosol, or nucleus (Table 1).

\section{Functional classification of CaS genes.}

All CaS clones were used to search the GenBank nonredundant public sequence database (Table 1) for similarities to known proteins using the BLASTX program and were classified into eight functional groups (Fig. 2).

Members of the largest group (27\%) were annotated as hypothetical proteins or proteins of unknown function in that they showed no or low sequence similarities to any protein with characterized functions. Twenty-six $\mathrm{CaS}$ genes (26\%) shared high similarities with defense- or stress-related proteins. Several members of PR protein and antifungal protein families were included in this group, which were known to play important roles in biotic or abiotic stresses (Kim et al. 2002; Oh et al. 1999). These included a chitinase (Hong and Hwang 2002), a germinlike protein (Park et al. 2004a), and a ribonuclease (Park et al. 2004b), which were previously characterized as stress-induced genes in pepper. Thus, these proteins likely have roles in apoplastic defense mechanisms.

Approximately $13 \%$ of the $\mathrm{CaS}$ genes were classified as proteases or protease inhibitors, and included members of the cysteine protease, subtilisin-like protease, and aspartyl protease families. Protease/protease inhibitors have been suggested to play a role in defense and the immune response against biotic stress (Dunaevskii Ia et al. 2005; van der Hoorn 2008); however, their specific modes of action and substrates in the interaction with pathogens are not well understood. A further $14 \%$ of the clones were predicted to encode cell wall structural proteins, including proline-rich proteins, glycine-rich proteins, extensin, cell adhesion protein, and U-rim protein. Another group of $\mathrm{CaS}$ genes $(4 \%)$ belonged to a general category of development and growth-related proteins, which includes organspecific growth protein, ripening-related protein, and expansinlike protein. The remaining CaS clones $(12 \%)$ were classified in the metabolism group, which includes proteins that contribute to the nutrient reservoir hydrolase, glutamine cyclotransferase, electron transporters, tonoplast intrinsic protein, and NADH dehydrogenase. These results suggested that the isolated $\mathrm{CaS}$ genes collectively contribute to both pathogen defense and the normal range of plant developmental process.

\section{Expression of CaS genes in resistant and susceptible plants following $P$. capsici infection.}

To address the molecular functions of $\mathrm{CaS}$ genes, we performed a reverse Northern blot (dot-blot) assay using RNA 
A Phytophthora capsici inoculation
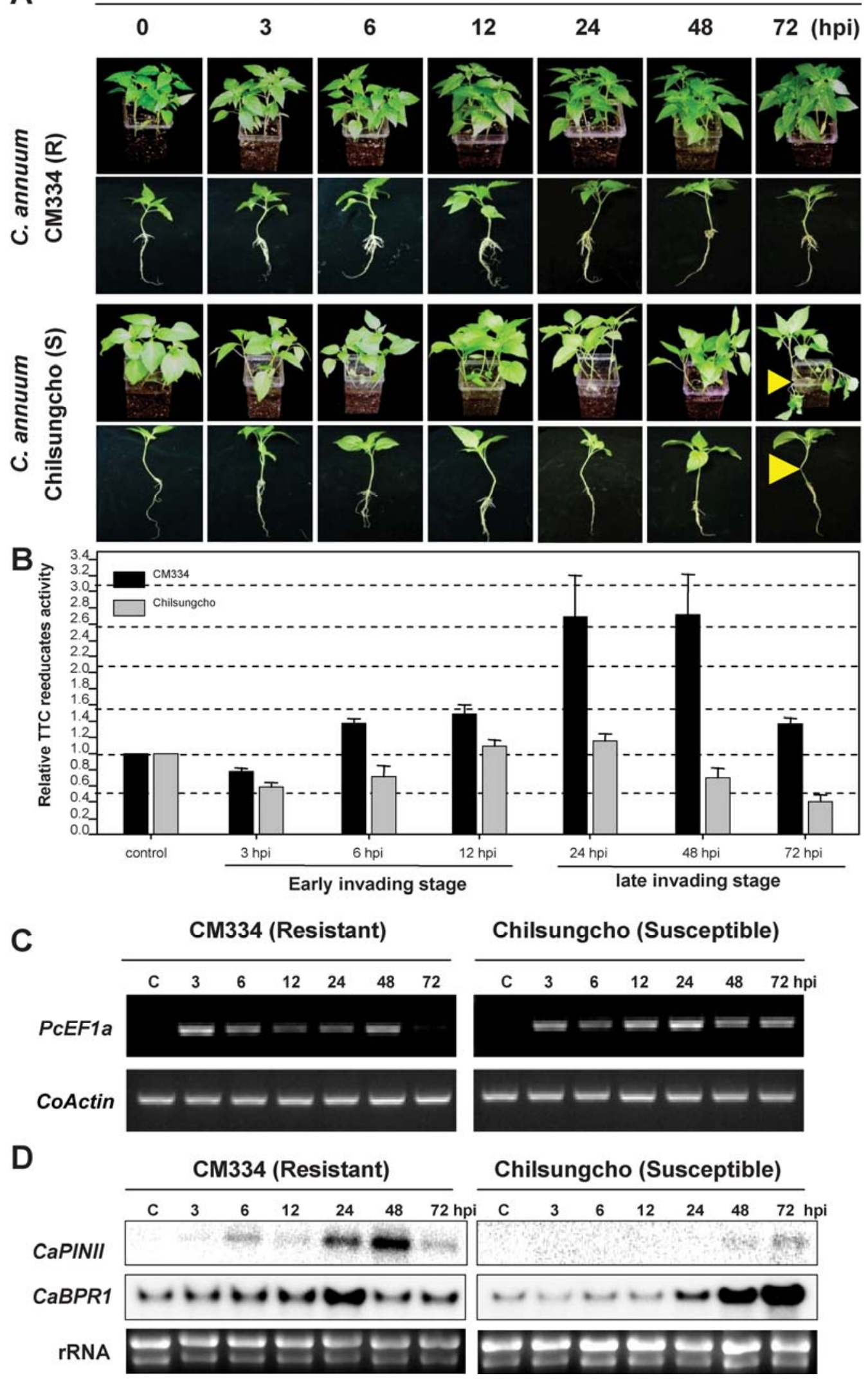

Fig. 1. Phenotype in resistant (Capsicum annuum CM334) and susceptible pepper (C. annuum Chilsungcho) roots. A, Symptoms observed at 72 h postinoculation (hpi) in Chilsungcho (susceptible, S) after drenching inoculation with zoospores of Phytophthora capsici $\left(2 \times 10^{5}\right.$ zoospores/ml). B, $2,3,5$-Triphenyltetrazolium chloride (TTC) reductase activity was also measured in resistant and susceptible pepper roots as cell vitality indicator. TTC reductase activity was normalized to that of noninfected root. Values are the means \pm standard deviation. C, Biomass of $P$. capsici in CM334 and Chilsungcho was assessed by the expression level of P. capsici elongation factor $1 \alpha$ (PcEF1 $\alpha$ ) gene. CoActin was used as control. D, Expression of pathogenesis-related (PR) genes during P. capsici infection in resistant and susceptible pepper cultivars. The CaBPRI and CaPINII genes were used to confirm the activation of defense-related genes. 
probes from different time points of infection $(0,3,6,12,24$, 48, and $72 \mathrm{hpi}$ ). Based on this analysis, altered expression patterns were observed for $68 \mathrm{CaS}$ genes relative to uninfected controls. The differential expression patterns of CaS mRNAs in resistant and susceptible cultivars of pepper following P. capsici infection are shown in Table 1 and Supplementary Table S1.
Of the $68 \mathrm{CaS}$ genes, 35 were induced in both resistant and susceptible plant interactions. Although these $35 \mathrm{CaS}$ genes showed similar expression patterns, $19 \mathrm{CaS}$ genes showed earlier and higher levels of expression in the resistant than in the susceptible cultivar (Table 1). Conversely, $14 \mathrm{CaS}$ genes showed earlier and higher levels of expression in the susceptible cultivar

Table 1. Yeast secretion trap clones isolated from Phytophthora capsici-infected pepper roots

\begin{tabular}{|c|c|c|c|c|c|c|c|c|}
\hline \multirow[b]{2}{*}{ Classification $^{\mathbf{b}}$} & \multirow[b]{2}{*}{ Pattern $^{c}$} & \multicolumn{3}{|c|}{ Database annotation } & \multicolumn{2}{|c|}{ SignalP 3.0 ${ }^{\mathrm{a}}$} & \multicolumn{2}{|c|}{$\begin{array}{c}\text { Predicted } \\
\text { localization }\end{array}$} \\
\hline & & Protein name & Accession $^{d}$ & E value ${ }^{e}$ & HMM & $\mathbf{N N}$ & TargetP $P^{f}$ & PSOPT $^{\mathrm{g}}$ \\
\hline \multicolumn{9}{|l|}{ Defense } \\
\hline $\mathrm{CaS} 1$ & $\mathrm{R}+$ & Ribonuclease T2 & ABB73003 & $2.0 \mathrm{E}-11$ & 1 & 0.907 & $\mathrm{~S}$ & Outside \\
\hline $\mathrm{CaS} 2$ & IB_R+ & Peroxidase & AAL35364 & $6.0 \mathrm{E}-116$ & 0.165 & 0.668 & $\mathrm{~S}$ & PM \\
\hline $\mathrm{CaS} 4$ & $\mathrm{R}+$ & Tobacco mosaic virus (TMV)-induced protein I & AAF63515 & $1.0 \mathrm{E}-76$ & 0.934 & 0.863 & $\mathrm{~S}$ & Outside \\
\hline CaS8 & IB_R+ & Class IV chitinase & BAF44533 & $8.0 \mathrm{E}-12$ & 0.992 & 0.822 & $\mathrm{~S}$ & Outside \\
\hline CaS12 & nc & Protein disulfide-isomerase & Q9XF61 & $9.0 \mathrm{E}-28$ & 0.997 & 0.825 & $\mathrm{~S}$ & Outside \\
\hline $\mathrm{CaS} 17$ & $\mathrm{R}+$ & TMV-induced protein 1-2 & AAO49266 & 7.0E-19 & 0.987 & 0.883 & $\mathrm{~S}$ & Outside \\
\hline $\mathrm{CaS} 22$ & IB_R+ & Putative peroxidase & CAC42086 & $2.0 \mathrm{E}-42$ & 1 & 0.786 & $\mathrm{~S}$ & Outside \\
\hline $\mathrm{CaS} 25$ & - & Peroxidase & AAA65637 & $2.0 \mathrm{E}-54$ & 0.984 & 0.906 & $\mathrm{~S}$ & PM \\
\hline $\mathrm{CaS} 30$ & $\mathrm{R}+$ & Antifungal protein & AAL73184 & $1.0 \mathrm{E}-30$ & 1 & 0.932 & $\mathrm{~S}$ & PM \\
\hline CaS54 & $\mathrm{R}+$ & Pathogenesis-related protein osmotin & AAC64171 & $3.0 \mathrm{E}-19$ & 0.983 & 0.925 & $\mathrm{~S}$ & Outside \\
\hline CaS57 & nc & Germin-like protein & NP_198731 & $6.0 \mathrm{E}-34$ & 0.972 & 0.857 & $\mathrm{~S}$ & PM \\
\hline CaS135 & IB_R+ & class 1 chitinase & BAC81645 & $5.0 \mathrm{E}-137$ & 0.989 & 0.938 & $\mathrm{~S}$ & PM \\
\hline $\mathrm{CaS} 160$ & IB_S+ & Allergen-like protein BRSn20 & AAF16869 & $1.0 \mathrm{E}-13$ & 1 & 0.859 & $\mathrm{~S}$ & Outside \\
\hline $\mathrm{CaS} 168$ & IB_R+ & SAR8.2A & AAX20029 & $4.0 \mathrm{E}-15$ & 0.971 & 0.889 & $\mathrm{~S}$ & Outside \\
\hline CaS175 & nc & Chitinase & CAA78844 & $5.0 \mathrm{E}-89$ & 1 & 0.928 & $\mathrm{~S}$ & Outside \\
\hline CaS182 & $\mathrm{R}+$ & Putative defensin AMP1 protein & AAL36289 & $3.0 \mathrm{E}-03$ & 0.997 & 0.877 & $\mathrm{~S}$ & Outside \\
\hline $\mathrm{CaS} 220$ & IB_R+ & Defensin protein & AAL35366 & $2.0 \mathrm{E}-07$ & 0.985 & 0.873 & $\mathrm{~S}$ & Outside \\
\hline $\mathrm{CaS} 221$ & IB_R+ & Wound-induced protein CBP1 & AAF18934 & $7.0 \mathrm{E}-37$ & 0.999 & 0.946 & $\mathrm{~S}$ & Outside \\
\hline CaS259 & IB_R+ & Pathogenesis-related protein $\mathrm{P} 2$ & CAA41439 & $9.0 \mathrm{E}-36$ & 0.992 & 0.826 & $\mathrm{~S}$ & Outside \\
\hline $\mathrm{CaS} 290$ & $\mathrm{IB}+$ & Pleiotropic drug resistance like protein & BAB92011 & $4.0 \mathrm{E}-72$ & $0.030^{(\mathrm{SA})}$ & 0.551 & $\mathrm{~S}$ & ER \\
\hline CaS359 & IB_R+ & Putative peroxidase & $\operatorname{cacn} 37$ & $1.0 \mathrm{E}-102$ & 1 & 0.905 & $\mathrm{~S}$ & Outside \\
\hline $\mathrm{CaS} 388$ & $\mathrm{IB}+$ & Pathogenesis-related protein $4 \mathrm{~b}$ & BAD11073 & $1.0 \mathrm{E}-06$ & 0.997 & 0.915 & $\mathrm{~S}$ & Outside \\
\hline $\mathrm{CaS} 390$ & IB_R+ & Putative gamma-thionin precursor & AAD21200 & $3.0 \mathrm{E}-32$ & 0.996 & 0.924 & $\mathrm{~S}$ & Outside \\
\hline CaS504 & $\mathrm{R}+$ & CPRD2 & BAB33033 & $9.0 \mathrm{E}-72$ & 0.933 & 1 & $\mathrm{~S}$ & Outside \\
\hline CaS507 & $\mathrm{R}+$ & Pathogenesis-related protein PR-1 & AAK30143 & $2.0 \mathrm{E}-75$ & 0.840 & 0.999 & $\mathrm{~S}$ & Outside \\
\hline CaS547 & nc & Thioredoxin & AAR83852 & $1.0 \mathrm{E}-16$ & 0.945 & 0.516 & $*$ & ER \\
\hline \multicolumn{9}{|l|}{ Protease } \\
\hline CaS102 & $\mathrm{R}+$ & Cathepsin B-like cysteine & AAR25800 & $3.0 \mathrm{E}-72$ & 0.994 & 0.905 & $\mathrm{~S}$ & Outside \\
\hline $\mathrm{CaS} 279$ & nc & Aspartyl protease family protein & NP_191467 & $3.0 \mathrm{E}-22$ & 0.998 & 0.929 & $\mathrm{~S}$ & Outside \\
\hline CaS450 & $\mathrm{nc}$ & Matrix metalloprotease 1 & ABF58910 & $2.0 \mathrm{E}-177$ & $0.002^{(\mathrm{SA})}$ & 0.118 & $*$ & PM \\
\hline $\mathrm{CaS} 457$ & IB_S+ & Putative subtilisin-like proteinase & XP_482712 & $7.0 \mathrm{E}-05$ & 0.999 & 0.852 & $\mathrm{~S}$ & Outside \\
\hline CaS13 & $\mathrm{R}+$ & Putative proteinase inhibitor II & AAF25496 & $4.0 \mathrm{E}-48$ & 0.985 & 0.904 & $\mathrm{~S}$ & Outside \\
\hline $\mathrm{CaS} 40$ & $\mathrm{R}+$ & Metallocarboxypeptidase inhibitor & AAZ94183 & $3.2 \mathrm{E}-01$ & 0.81 & 0.743 & $\mathrm{~S}$ & Outside \\
\hline CaS64 & - & Putative invertase inhibitor & AAX63191 & $1.0 \mathrm{E}-22$ & 0.507 & 0.435 & $\mathrm{C}$ & ER \\
\hline CaS153 & IB_S+ & Putative miraculin & CAC40756 & $5.0 \mathrm{E}-17$ & 0.999 & 0.77 & $\mathrm{~S}$ & Outside \\
\hline CaS333 & $\mathrm{R}+$ & Ethylene-responsive proteinase inhibitor 1 & AAA60745 & $6.0 \mathrm{E}-13$ & 1 & 0.935 & $\mathrm{~S}$ & Outside \\
\hline $\mathrm{CaS} 360$ & IB_R+ & Cystatin & AAR92224 & $2.0 \mathrm{E}-03$ & 0.983 & 0.782 & $\mathrm{~S}$ & Outside \\
\hline CaS439 & $\mathrm{nc}$ & Opening-related protein-like & AAM62643 & $6.0 \mathrm{E}-21$ & 0.984 & 0.786 & $\mathrm{~S}$ & ER \\
\hline CaS475 & IB_S+ & Trypsin proteinase inhibitor precursor & ABA42905 & $3.0 \mathrm{E}-04$ & 0.995 & 0.798 & $\mathrm{~S}$ & Outside \\
\hline CaS551 & IB_S+ & Putative kunitz-type proteinase inhibitor & AF492358_1 & $2.0 \mathrm{E}-47$ & 0.949 & 0.998 & $\mathrm{~S}$ & Outside \\
\hline \multicolumn{9}{|l|}{ Cell wall } \\
\hline $\mathrm{CaS} 3$ & $\mathrm{R}+$ & Glycine-rich protein Tfm5 & X95262 & $4.0 \mathrm{E}-52(\mathrm{n})$ & 0.998 & 0.862 & $\mathrm{~S}$ & Outside \\
\hline $\mathrm{CaS} 16$ & $\mathrm{R}+$ & Cell wall protein 3 & CAJ13710 & $4.0 \mathrm{E}-08$ & 0.997 & 0.918 & $\mathrm{~S}$ & Outside \\
\hline CaS58 & $\mathrm{R}+$ & Fasciclin-like AGP 12 & AAT37955 & $8.0 \mathrm{E}-61$ & 0.997 & 0.884 & $\mathrm{~S}$ & Outside \\
\hline CaS67 & - & Extensin & Z21937 & $2 \mathrm{E}-100(\mathrm{n})$ & 0.999 & 0.851 & $\mathrm{~S}$ & Outside \\
\hline \multirow[t]{2}{*}{ CaS71 } & $\mathrm{nc}$ & Putative membrane protein & CAC37357 & $3.0 \mathrm{E}-15$ & 0.998 & 0.907 & $\mathrm{~S}$ & Outside \\
\hline & & & & & & \multicolumn{3}{|c|}{ (continued on next page) } \\
\hline
\end{tabular}

${ }^{a}$ Signal peptide was predicted by SignalP3.0. $(\mathrm{SA})=$ signal anchor and no predicted signal peptide was indicated scores as bold. HMM and NN = hidden Markov model and neural network methods, respectively.

${ }^{\mathrm{b}}$ Classification abbreviations: Defense $=$ defense- or resistance-related proteins, Protease $=$ protease or protease inhibitor, Cell wall $=$ cell wall structure protein, Growth = development or growth-related protein, and Hypothetical = hypothetical protein or unknown. Capsicum annuum secretome $($ CaS $)$ names $=$ C. annuum 'CM334"-Phytophthora capsici interaction secretome.

${ }^{\mathrm{c}}$ Expression pattern of each gene by dot-blot assay. IB_R $+=$ induced in both pepper cultivars (resistant and susceptible) but earlier and higher expression in resistant pepper; IB-S+ = induced in both cultivars but earlier and higher expression in susceptible pepper; IB $+=$ similar expression in both cultivars; R $+=$ induced in resistant pepper but no change or reduced in susceptible pepper; $-=$ repressed in both; nc $=$ transcripts $>0.5$-fold and $<2$-fold or no changes in expression profiling.

${ }^{\mathrm{d}}$ Pepper expressed sequence tag database: cacn or caKS accession, Gene Pool; SGN accession, Sol Genomic Network.

e E value from protein blast or blastx; $(n)=$ nucleotide blast.

${ }^{\mathrm{f}}$ Prediction of localization by TargetP program. $\mathrm{S}=$ secretory pathway, $\mathrm{C}=$ chloroplast, $-=$ any other localization, and $*=$ don't know. In this analysis, specificity $>0.95$ (predefined set of cutoffs that yielded this specificity on the TargetP test sets).

${ }^{\mathrm{g}}$ Sublocalization by PSORT program. Outside $=$ cell wall or extracellular space, $\mathrm{N}=$ nucleus, Cyto = cytoplasm, PM $=$ plasma membrane, ER = endoreticulum, $\mathrm{Mt}=$ mitochondrion, $\mathrm{Mb}=$ microbody (peroxisome), Too short = amino acid too short for prediction. 
while $2 \mathrm{CaS}$ genes showed similar expression in both cultivars. On the other hand, $27 \mathrm{CaS}$ genes were upregulated in the resistant cultivar but showed no significant changes in the susceptible cultivar. Expression levels of six $\mathrm{CaS}$ genes were reduced in both cultivars, compared with the controls (Table 1). The remaining $33 \mathrm{CaS}$ genes showed no significant expression level changes in this comparison.
For more precise monitoring of expression levels of $\mathrm{CaS}$ genes between resistant and susceptible cultivars, we selected only the differentially expressed $\mathrm{CaS}$ genes for quantitative real-time reverse-transcription polymerase chain reaction (qRT-PCR) analyses. Based on representative qRT-PCR, gene expression patterns could be divided into four groups: the first showed early induction before the onset of the hypersensitive

Table 1. (continued from preceding page)

\begin{tabular}{|c|c|c|c|c|c|c|c|c|}
\hline \multirow[b]{2}{*}{ Classification $^{\mathbf{b}}$} & \multirow[b]{2}{*}{ Pattern $^{\mathrm{c}}$} & \multicolumn{3}{|c|}{ Database annotation } & \multicolumn{2}{|c|}{ SignalP 3.0 ${ }^{\mathrm{a}}$} & \multicolumn{2}{|c|}{$\begin{array}{c}\text { Predicted } \\
\text { localization }\end{array}$} \\
\hline & & Protein name & Accession $^{\mathrm{d}}$ & E value ${ }^{\mathrm{e}}$ & HMM & NN & TargetP $P^{f}$ & PSOPT $^{\mathrm{g}}$ \\
\hline CaS81 & - & Glycine-rich protein 2 & CAA42622 & $6.0 \mathrm{E}-26$ & $0.260^{(\mathrm{SA})}$ & 0.679 & $\mathrm{~S}$ & Outside \\
\hline $\mathrm{CaS} 100$ & $\mathrm{R}+$ & Cell wall protein & AAF63514 & $5.0 \mathrm{E}-41$ & 0.995 & 0.907 & $\mathrm{~S}$ & Outside \\
\hline $\mathrm{CaS} 114$ & $\mathrm{nc}$ & Extensin-like protein & Z46675 & 7E-46(n) & 0 & 0.178 & $*$ & Too short \\
\hline CaS171 & $\mathrm{R}+$ & Glycine-rich protein TomR2 & AAP83840 & $3.0 \mathrm{E}-10$ & 0.996 & 0.904 & $\mathrm{~S}$ & Outside \\
\hline $\mathrm{CaS} 203$ & - & Putative proline-rich protein & AAC49600 & $5.0 \mathrm{E}-04$ & 0.995 & 0.847 & $\mathrm{~S}$ & Outside \\
\hline $\mathrm{CaS} 216$ & IB_S+ & Extensin & NP_568813 & 4.0E-16 & 0.939 & 0.757 & $\mathrm{~S}$ & ER \\
\hline $\mathrm{CaS} 236$ & $\mathrm{IB} \mathrm{R}_{+}$ & EXPANSIN-LIKE B1 & NP_193436 & $1.0 \mathrm{E}-21$ & 0.984 & 0.891 & $\mathrm{~S}$ & Outside \\
\hline $\mathrm{CaS} 283$ & $\mathrm{nc}$ & U-Lim protein & AAR83883 & $3.0 \mathrm{E}-15$ & 0.998 & 0.921 & $\mathrm{~S}$ & Outside \\
\hline $\mathrm{CaS} 319$ & IB_R+ & Fiber protein $\mathrm{Fb} 34$ & AAR07596 & $2.0 \mathrm{E}-13$ & 0.939 & 0.838 & S & $\mathrm{PM}$ \\
\hline \multicolumn{9}{|l|}{ Metabolism } \\
\hline $\mathrm{CaS} 20$ & $\mathrm{nc}$ & Arabinosidase ARA-1 & AAL18931 & 7.0E-24 & 0.997 & 0.807 & $\mathrm{~S}$ & Outside \\
\hline $\mathrm{CaS} 23$ & IB_R+ & Putative high-affinity nitrate transporter & AAF00053 & $4.0 \mathrm{E}-54$ & 0.002 & 0.099 & - & ER \\
\hline CaS44 & IB_S+ + & ARIADNE-like protein & AAR96008 & $6 . \mathrm{E}-05$ & 0.006 & 0.519 & $*$ & ER \\
\hline CaS76 & $\mathrm{nc}$ & Aquaglyceroporin & CAB40742 & $2.0 \mathrm{E}-25$ & $0.413^{(\mathrm{SA})}$ & 0.48 & $\mathrm{~S}$ & PM \\
\hline CaS97 & IB_S+ & Dihydropyrimidinase/ hydrolase & NP_568258 & $2.0 \mathrm{E}-87$ & 0.997 & 0.811 & $\mathrm{~S}$ & Outside \\
\hline $\mathrm{CaS} 111$ & IB_S+ & NADH dehydrogenase subunit 5 & ABD36074 & $5.0 \mathrm{E}-32$ & 0.989 & 0.84 & $\mathrm{~S}$ & PM \\
\hline $\mathrm{CaS} 245$ & $\mathrm{IB} \mathrm{S}_{+}$ & Electron transporter & NP_568926 & $6.0 \mathrm{E}-64$ & 1 & 0.811 & $\mathrm{~S}$ & Outside \\
\hline $\mathrm{CaS} 253$ & $\mathrm{nc}$ & Vacuolar sorting receptor 6 & Q9FYH7 & $2.0 \mathrm{E}-88$ & 0.791 & 0.954 & $\mathrm{~S}$ & Outside \\
\hline $\mathrm{CaS} 256$ & $\mathrm{R}+$ & Glutamine cyclotransferase like & ABB86263 & 4.0E-17 & 0.995 & 0.822 & $\mathrm{~S}$ & Outside \\
\hline $\mathrm{CaS} 257$ & $\mathrm{R}+$ & Copper ion binding / electron transporter & NP_563820 & 7.0E-23 & 0.964 & 0.928 & $\mathrm{~S}$ & Outside \\
\hline CaS336 & $\mathrm{nc}$ & Protein carrier & NP_564256. & $5.0 \mathrm{E}-37$ & 0.904 & 0.879 & $\mathrm{~S}$ & Outside \\
\hline CaS389 & IB_R+ & Hydrolase & NP_177929 & $3.0 \mathrm{E}-44$ & 0.988 & 0.858 & $*$ & Outside \\
\hline \multicolumn{9}{|l|}{ Signal } \\
\hline $\mathrm{CaS} 10$ & $\mathrm{nc}$ & Receptor like kinase & NP_198716 & $2.0 \mathrm{E}-46$ & 0.999 & 0.789 & $\mathrm{~S}$ & Outside \\
\hline CaS70 & $\mathrm{nc}$ & Kinase & NP_849788 & $9.0 \mathrm{E}-02$ & 0.998 & 0.756 & $\mathrm{~S}$ & PM \\
\hline $\mathrm{CaS} 88$ & $\mathrm{nc}$ & Receptor protein kinase-like protein & CAB 81062 & 7.0E-21 & 0.129 & 0.517 & $\mathrm{~S}$ & PM \\
\hline \multicolumn{9}{|l|}{ Growth } \\
\hline CaS5 & IB_R+ & FH protein NFH1 & AAF24496 & $3.5 \mathrm{E}-02$ & 0.998 & 0.916 & $\mathrm{~S}$ & Outside \\
\hline CaS75 & - & Putative ROX1 & ABH01084 & $1.0 \mathrm{E}-28$ & 0.999 & 0.85 & $\mathrm{~S}$ & Outside \\
\hline $\mathrm{CaS} 404$ & $\mathrm{nc}$ & Organ-specific protein $\mathrm{P} 4$ & P17771 & $1.0 \mathrm{E}-04$ & 1 & 0.91 & S & Outside \\
\hline CaS502 & $\mathrm{nc}$ & Putative auxin-independent growth promoter & BAD69015. & $8.0 \mathrm{E}-13$ & $0.416^{(\mathrm{SA})}$ & 0.869 & $*$ & PM \\
\hline \multicolumn{9}{|l|}{ Others } \\
\hline $\mathrm{CaS} 200$ & $\mathrm{nc}$ & Retrotransposon protein & None & None & 0.213 & 0.135 & $*$ & $\mathrm{Mb}$ \\
\hline CaS209 & $\mathrm{nc}$ & Ribosomal protein PETRP & AAR83848 & $2.0 \mathrm{E}-63$ & 0.024 & 0 & $*$ & Cyto \\
\hline \multicolumn{9}{|l|}{ Hypothetical } \\
\hline $\mathrm{CaS} 11$ & IB_S+ & Hypothetical protein & None & None & 0.989 & 0.814 & $\mathrm{~S}$ & Outside \\
\hline CaS89 & $\mathrm{nc}$ & Hypothetical protein & None & None & $0.000^{(\mathrm{SA})}$ & 0 & S & $\mathrm{PM}$ \\
\hline $\mathrm{CaS} 113$ & IB_R+ & Hypothetical protein & None & None & 0.997 & 0.874 & S & Outside \\
\hline $\mathrm{CaS} 148$ & $\mathrm{R}+$ & Hypothetical protein & None & None & 0.999 & 0.758 & $S$ & Outside \\
\hline $\mathrm{CaS} 150$ & $\mathrm{R}+$ & Hypothetical protein & None & None & $0.187^{(\mathrm{SA})}$ & 0.479 & $\mathrm{~s}$ & $\mathrm{Mt}$ \\
\hline $\mathrm{CaS} 162$ & IB_R+ & Hypothetical protein & None & None & 0.801 & 0.911 & $\mathrm{~S}$ & Outside \\
\hline $\mathrm{CaS} 163$ & $\mathrm{nc}$ & Hypothetical protein & None & None & $0.005^{(\mathrm{SA})}$ & 0.223 & - & ER \\
\hline CaS194 & $\mathrm{Nc}$ & Hypothetical protein & None & None & 0.999 & 0.805 & $\mathrm{~S}$ & Outside \\
\hline $\mathrm{CaS} 202$ & $\mathrm{nc}$ & Hypothetical protein & None & None & 0.998 & 0.885 & $\mathrm{~S}$ & Outside \\
\hline $\mathrm{CaS} 238$ & $\mathrm{R}+$ & Hypothetical protein & None & None & 1 & 0.892 & $\mathrm{~S}$ & Outside \\
\hline $\mathrm{CaS} 260$ & $\mathrm{nc}$ & Hypothetical protein & None & None & 0.083 & 0 & $\mathrm{C}$ & Cyto \\
\hline $\mathrm{CaS} 270$ & IB_S+ & Hypothetical protein & None & None & 0.903 & 0.992 & $\mathrm{~S}$ & Outside \\
\hline $\mathrm{CaS} 284$ & $\mathrm{R}+$ & Hypothetical protein & None & None & 0.999 & 0.929 & $\mathrm{~S}$ & Outside \\
\hline $\mathrm{CaS} 369$ & $\mathrm{nc}$ & Hypothetical protein & None & None & 0 & 0.342 & * & $\mathrm{Mb}$ \\
\hline CaS411 & $\mathrm{R}+$ & Hypothetical protein & None & None & 0.001 & 0.468 & $\mathrm{~S}$ & Cyto \\
\hline $\mathrm{CaS} 431$ & $\mathrm{nc}$ & Hypothetical protein & caKS15062F02 & $6.0 \mathrm{E}-75$ & 0 & 0.377 & $*$ & Too short \\
\hline CaS449 & $\mathrm{nc}$ & Hypothetical protein & None & None & 0.867 & 0.838 & $\mathrm{~S}$ & Outside \\
\hline $\mathrm{CaS} 463$ & $\mathrm{nc}$ & Hypothetical protein & EAZ07418.1 & $6.0 \mathrm{E}-48$ & 0.013 & 0.279 & - & $\mathrm{N}$ \\
\hline $\mathrm{CaS} 464$ & $\mathrm{R}+$ & Hypothetical protein & None & None & 0.994 & 0.883 & $\mathrm{~S}$ & Outside \\
\hline $\mathrm{CaS} 472$ & $\mathrm{R}+$ & Hypothetical protein & None & None & $0.178^{(\mathrm{SA})}$ & 0.546 & $S$ & ER \\
\hline CaS501 & - & Hypothetical protein & SGN-U330124 & $1.0 \mathrm{E}-82$ & 0.949 & 0.996 & S & Outside \\
\hline CaS503 & $\mathrm{R}+$ & Hypothetical protein & None & None & 0.958 & 0.981 & $S$ & Outside \\
\hline $\mathrm{CaS} 505$ & IB_R+ & Hypothetical protein & None & None & 0.951 & 0.972 & $S$ & PM \\
\hline $\mathrm{CaS} 226$ & $\mathrm{nc}^{-}$ & Unknown & cacn 8472 & $9 \mathrm{E}-62$ & 1 & 0.923 & $\mathrm{~S}$ & Outside \\
\hline $\mathrm{CaS} 229$ & IB_S+ & Unknown & caKS17001A12 & $4.0 \mathrm{E}-26$ & 0 & 0.035 & - & $\mathrm{Mb}$ \\
\hline CaS356 & IB_S+ & Unknown & NP_564344.1 & $2.0 \mathrm{E}-09$ & 0.992 & 0.794 & $\mathrm{~S}$ & Outside \\
\hline $\mathrm{CaS} 456$ & $\mathrm{nc}$ & Unknown & XP_002326189 & $4.0 \mathrm{E}-04$ & $0.351^{(\mathrm{SA})}$ & 0.844 & $S$ & Outside \\
\hline
\end{tabular}


response (HR); the second group showed late induction at 12 hpi, and remained at the higher level until $72 \mathrm{hpi}$; the third group showed stronger induction in the susceptible than the resistant cultivar; and the fourth group showed decreased transcript levels following $P$. capsici infection (Fig. 3). Under the same conditions, the transcripts of CaS102 and CaS113 increased earlier, at $3 \mathrm{hpi}$, in the resistant cultivar. The CaS290 gene was expressed as early as 3 hpi in both cultivars (Fig. $3 \mathrm{~A})$. The time points for appearance of $\mathrm{CaS} 22, \mathrm{CaS148}$, and CaS259 transcripts were late stage, from 24 to 72 hpi in both cultivars (Fig. 3B). Interestingly, some CaS clones (CaS162, CaS475, and CaS551) were much more upregulated in the susceptible cultivar, most notably CaS551, whose expression level was eight times higher (Fig. 3C). Finally, the genes of the fourth group showed decreased or abolished expression during $P$. capsici infection (Fig. 3D). This class, which includes CaS67 (extensin) and CaS203 (putative proline-rich protein [PRP]), major structural cell wall proteins (Bernhardt and Tierney 2000; Fowler et al. 1999; Niebel et al. 1993), was downregulated but gradually recovered in the resistant cultivar and not in the susceptible one. Extensin and PRP play a role in the plant response to pathogen attack (Hematy et al. 2009) and, therefore, their downregulation may be involved in effective invasion of the pathogen (Wei and Shirsat 2006).

The expression patterns of the qRT-PCR analysis largely agreed with those of the dot-blot assay. Taken together, these results indicated that the YST technique could be efficiently used for isolation of pathogen-responsive secreted proteins in the pepper-P. capsici interaction.

\section{Roles of CaS genes in development and cell death in pepper plants.}

Expression analysis indicated that many $\mathrm{CaS}$ genes might have a role in defense responses (Fig. 3). To test this, a loss-offunction strategy was taken using the TRV-based virus-induced gene silencing (VIGS) method for gene knock-down (Chung et al. 2004; Liu et al. 2002). The VIGS experiments were performed in chili pepper plants with $68 \mathrm{CaS}$ genes.

We observed that silencing of only three $\mathrm{CaS}$ genes led to phenotypic abnormalities at 3 to 4 weeks after VIGS. CaS17-, CaS221-, and CaS259-silenced pepper plants showed retarded growth compared with green fluorescent protein (GFP)silenced control plants. We also observed delay of cell death following Pseudomonas syringae pv. tomato $\mathrm{T} 1$ inoculation in 8 of $68 \mathrm{CaS}$ gene-silenced cases: CaS75, CaS113, CaS203, CaS259, CaS270, CaS389, CaS390, and CaS501 (Fig. 4; Supplementary Fig. S3). Among these, CaS259, which showed both cell death suppression by $P$. syringae pv. tomato $\mathrm{T} 1$ and phenotypic abnormalities, was selected for validation of the gene-silencing effects.

We measured plant height in CaS259-silenced pepper plants. The growth of CaS259-silenced pepper showed severe growth retardation (40\% of control) (Fig. 5A). RT-PCR was performed to verify the suppression of $\mathrm{CaS} 259$ gene expression in the silenced plant (Fig. 5A). These results indicate that the aberrant phenotype correlates with the suppression of transcript level of gene CaS259. To validate the effect of CaS259 silencing on pathogen-induced cell death, leaves of the CaS259-silenced pepper were inoculated with Xanthomonas axonopodis pv. glycines 8ra (optical density $=0.1$ ), a non-host pathogen of pepper (Oh et al. 2008; Yi et al. 2009). The cell death induced by $X$. axonopodis pv. glycines 8ra was significantly delayed in CaS259-silenced pepper plants compared with that of control plants (Fig. 5C). Ion leakage was also significantly reduced compared with that of control plants during $X$. axonopodis pv. glycines 8ra inoculation (Fig. 5D).

We also determined the effects of silencing of selected $\mathrm{CaS}$ genes (Fig. 4) in resistant pepper (CM334) following P. capsici inoculation. Only CaS259-silenced plant significantly showed reduction in cell death challenged by Phytophthora capsici

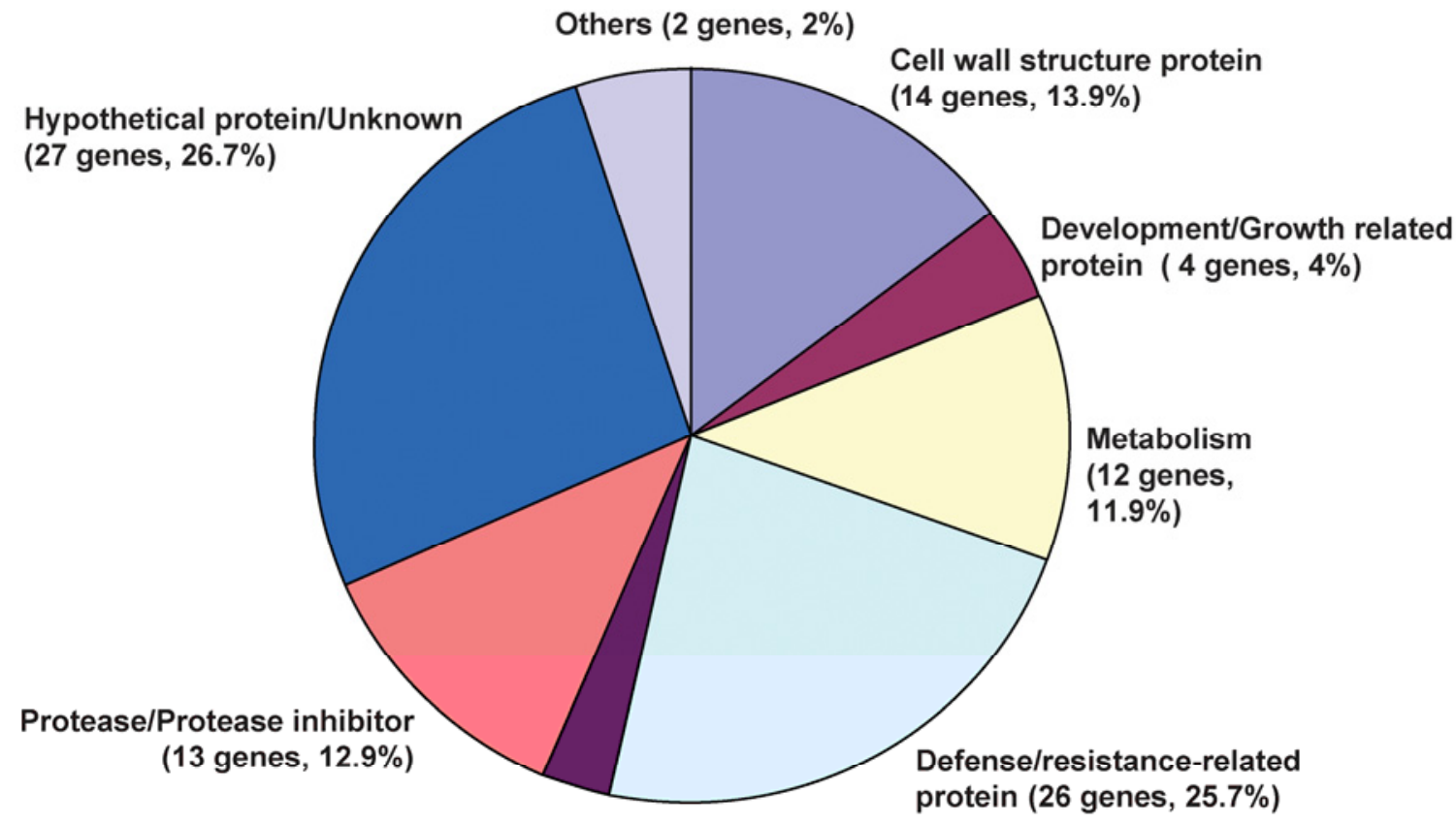

Signal (3 genes, $3 \%$ )

Fig. 2. Functional classification of Capsicum annuum secretome (CaS). In all, $101 \mathrm{CaS}$ genes were isolated. Based on the sequence analysis using the BlastX algorithm with the $\mathrm{nr}$ database of the National Center for Biotechnology Information, the genes were classified into eight categories: 27 genes of unknown function, 26 genes in defense or resistance, 18 genes in development or growth of cell wall structure, 12 genes in metabolism, and 13 genes in protease or protease inhibitor. The remaining five genes were grouped in signal-related genes and others. Representative clones described in each group are shown in parentheses. 
(Supplementary Fig. S4; Fig. 6A). The index of cell death and $P$. capsici colonization in CaS259-silenced resistant pepper were decreased compared with those of control plant (Fig. 6B and $\mathrm{C}$ ). The expression levels of $\mathrm{CaHinl}$ and $\mathrm{CaCDM1}$ genes, cell death markers, were decreased and the $\mathrm{CaPRl}$ gene was downregulated in the CaS259-silenced resistant pepper following pathogen infection (Supplementary Fig. S1). We also performed the VIGS assay of the CaS259 gene in susceptible pepper plants following $P$. capsici inoculation. Disease symptoms and $P$. capsici colonization were also decreased in CaS259-silenced susceptible pepper compared with those of control (Fig. 7 ). These data suggested that one of the pathogen-responsive secreted proteins identified, CaS259, has an important role in both normal growth and the modulation of cell death induced by pathogen in pepper plants.

\section{DISCUSSION}

The goal of this study was to isolate the secreted proteins of pepper resistant to $P$. capsici infection for comparison of transcript profiles between susceptible and resistant cultivars. We isolated 101 secreted proteins using the YST system from $P$. capsici-infected pepper roots. Of the 101 unique sequences, 92 $(92 \%)$ contained a predicted secretory signal peptide. The other
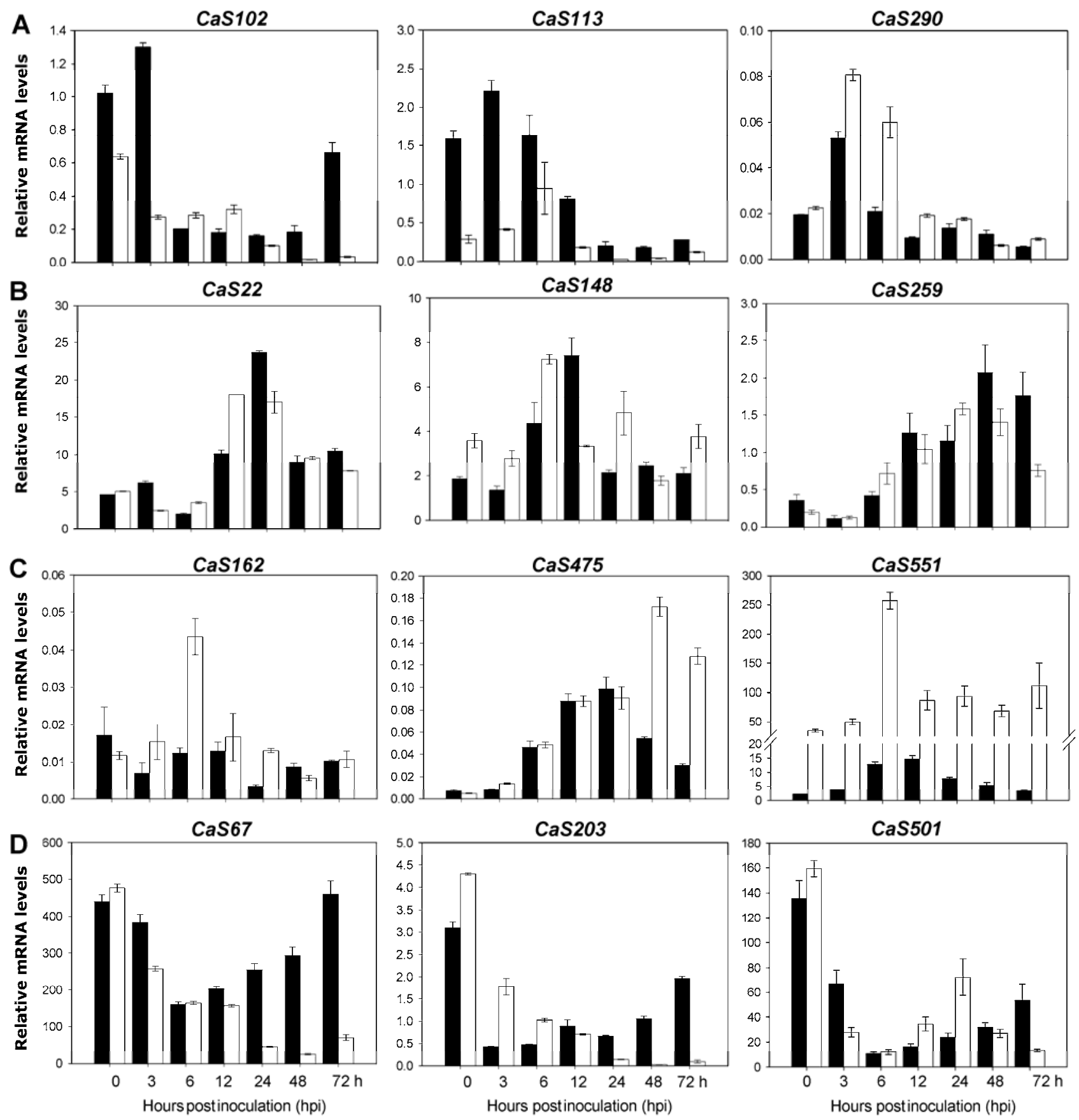

Fig. 3. Representative quantitative reverse-transcription polymerase chain reaction (qRT-PCR) of several Capsicum annuum secretome (CaS) clones. Total RNAs were isolated at different time points following inoculation of Phytophthora capsici into roots of resistant and susceptible pepper plants. qRT-PCRs were performed on cDNA using gene-specific primers for each CaS clone. Each bar represents the value of relative gene expression at different time points following inoculation of $P$. capsici for indicated CaS gene, between resistant pepper (black bar, CM334) and susceptible pepper (white bar, Chilsungcho) plants. The expression of $\mathrm{CaS}$ genes was normalized to the expression of CoActin. Values were calculated for CaS genes following three replications and standard deviations are shown. Similar results were obtained from at least two independent experiments. One representative experiment is shown. 
nine CaS genes might be "false positives", because some truncated proteins could exhibit unnaturally exposed N-terminal hydrophobic or highly basic regions and, thus, be artificially secreted, or they might be secreted through noncanonical pathways (Rose and Lee 2010). Nevertheless, the rate of signal sequence recovery is high compared with previous studies, showing 76 to $83 \%$ using other signal-sequence trap technologies with tobacco or Arabidopsis (Goo et al. 1999; Hugot et al. 2004). Several CaS genes (CaS1, CaS2, CaS67, CaS203, $\mathrm{CaS388}$, and CaS507) encode well-known secreted cell wall or extracellular proteins, which confirmed that our experimental system worked for the pepper-Phytophthora interaction (Table $1)$. However, the large proportion of unknown secreted proteins (27 genes) suggests that many functions of secreted proteins still remained to be elucidated.

We did not find any pathogen-derived secreted proteins by computational analysis of these clones after searching numerous DNA databases. In this regard, our results differed from those of Lee and associates (2006a), who reported that the same YST system was valuable for the identification of both host- and pathogen-derived secreted proteins involved in the interaction between tomato (Solanum lycopersicum) and the oomycete $P$. infestans. This difference might reflect the susceptible or resistant interaction between pathogen and plant host. In our study, we constructed the YST cDNA library from resistant pepper following $P$. capsici infection, which may have resulted in undetectable levels of pathogen biomass compared with that of the susceptible interaction used by Lee and associates (2006a). It is also possible that the greater abundance of plant cDNA encoding secreted proteins prevented detection of pathogen-derived cDNAs, which are relatively rare.

The transcript levels of a number of $\mathrm{CaS}$ genes were significantly changed in resistant or susceptible cultivars following $P$. capsici infection. The differences in $\mathrm{CaS}$ transcripts could be grouped by temporal changes and by transcript levels between the susceptible and resistant cultivars (Fig. 3). These results are consistent with the observations of Richins and associates (2010), who showed global gene expression profiles using microarrays in resistant and susceptible pepper cultivars infected by $P$. capsici. The gene expression profiling allowed us to determine differentiation of expression at the molecular level between resistance and susceptibility to pathogen.

To select $\mathrm{CaS}$ genes related to the defense response to pathogen, $68 \mathrm{CaS}$ genes affected by pathogen infection were selected for gene silencing. We observed only three $\mathrm{CaS}$ genes that induced significant morphological change in silenced pepper plants, which were assumed to be defense-related proteins and not cell wall structure-related proteins (Table 1; Figs. 3 and 4). According to in silico analyses, $18 \mathrm{CaS}$ clones were predicted to be cell wall structural protein or growth- or development-related protein. However, when $\mathrm{CaS}$ genes were silenced in Nicotiana benthamiana, 31 of $68 \mathrm{CaS}$ genes (approximately 50\%) showed morphological abnormalities, such as curly leaves, stunted growth, and severe developmental defects (data not shown). It could be that the efficiency of gene silencing in pepper is less uniform than in $N$. benthamiana (Dong et al. 2007; Liu et al. 2004).

Gene silencing experiments also revealed that eight $\mathrm{CaS}$ genes compromised cell death following Pseudomonas syringae pv. tomato $\mathrm{T} 1$ infection, to less than $20 \%$ relative to the control (Fig. 4). Of these, three (CaS113, CaS270, and CaS501) are classified in the hypothetical protein/unknown function group. Two CaS genes ( $\mathrm{CaS} 259$ and $\mathrm{CaS} 390)$ belong to PR gene families and defensin, which are well known to act on plant defense showing anti-bacterial or antifungal activity, respectively (Pelegrini and Franco 2005; van Loon et al. 2006). The remaining $\mathrm{CaS}$ genes can be classified within the groups of cell wall structure (CaS203, putative PRP), metabolism (CaS389, hydrolase), and development- or growth-related proteins (CaS75, putative ROX1) (Cecchetti et al. 2007).
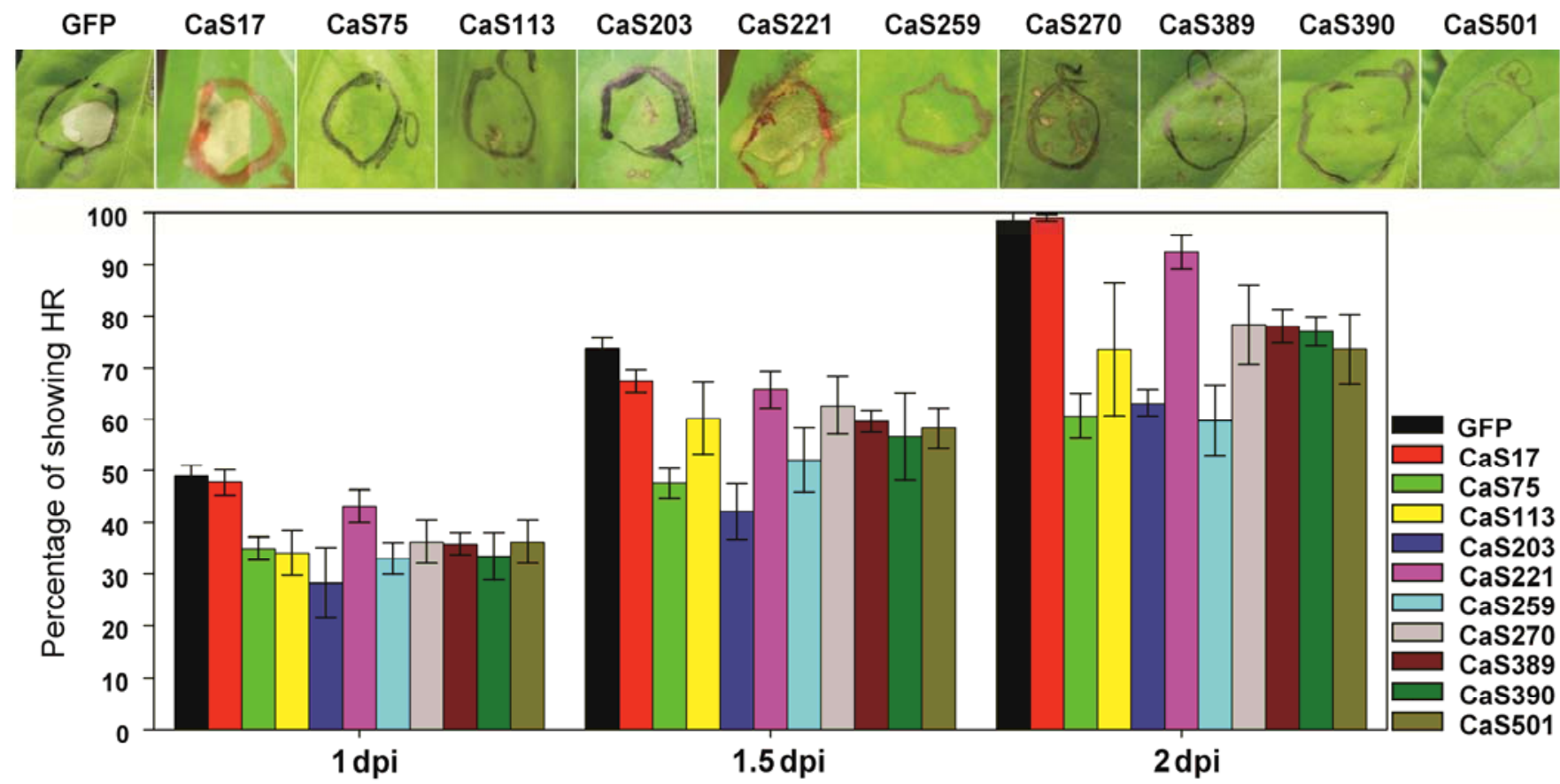

$P$. syringae pv. tomato $\mathrm{T} 1$ infection

Fig. 4. Hypersensitive response (HR) of representative Capsicum annuum secretome (CaS) gene-silenced pepper following bacterial pathogen (Pseudomonas syringae pv. tomato T1). CaS gene-silenced pepper plants were infiltrated with non-host bacterial pathogen $P$. syringae pv. tomato T1 (optical density at $600 \mathrm{~nm}=0.05$ ). The HR symptoms were taken at 2 days postinoculation (upper panel). Delay of HR by $P$. syringae pv. tomato T1 was scored by the mean percentages of sites showing cell death (lower panel). Standard deviations were scored from 15 infiltration site per line, comprising three leaves from five independent plants. Similar results were obtained from at least two independent experiments. One representative experiment is shown. 
To validate these findings, the CaS259 gene was chosen and the gene-silenced pepper was infected with a non-host pathogen, $X$. axonopodis pv. glycines 8ra. The cell-death delay was determined by scoring for ion leakage (Fig. 5D). In addition, the cell death symptoms and Phytophthora capsici infection were reduced in both the resistant and susceptible pepper plants following silencing of CaS259 gene (Figs. 6 and 7). In contrast, biomass of $P$. capsici was increased in CaS259 transient overexpressed $N$. benthamiana compared with that of the control (Supplementary Fig. S6). These data suggested that the function of CaS259 might be related to susceptibility factor for $P$. capsici, or else the pleiotropic effects of CaS259-silencing in pepper have rendered the plant more resistant, showing celldeath delay.
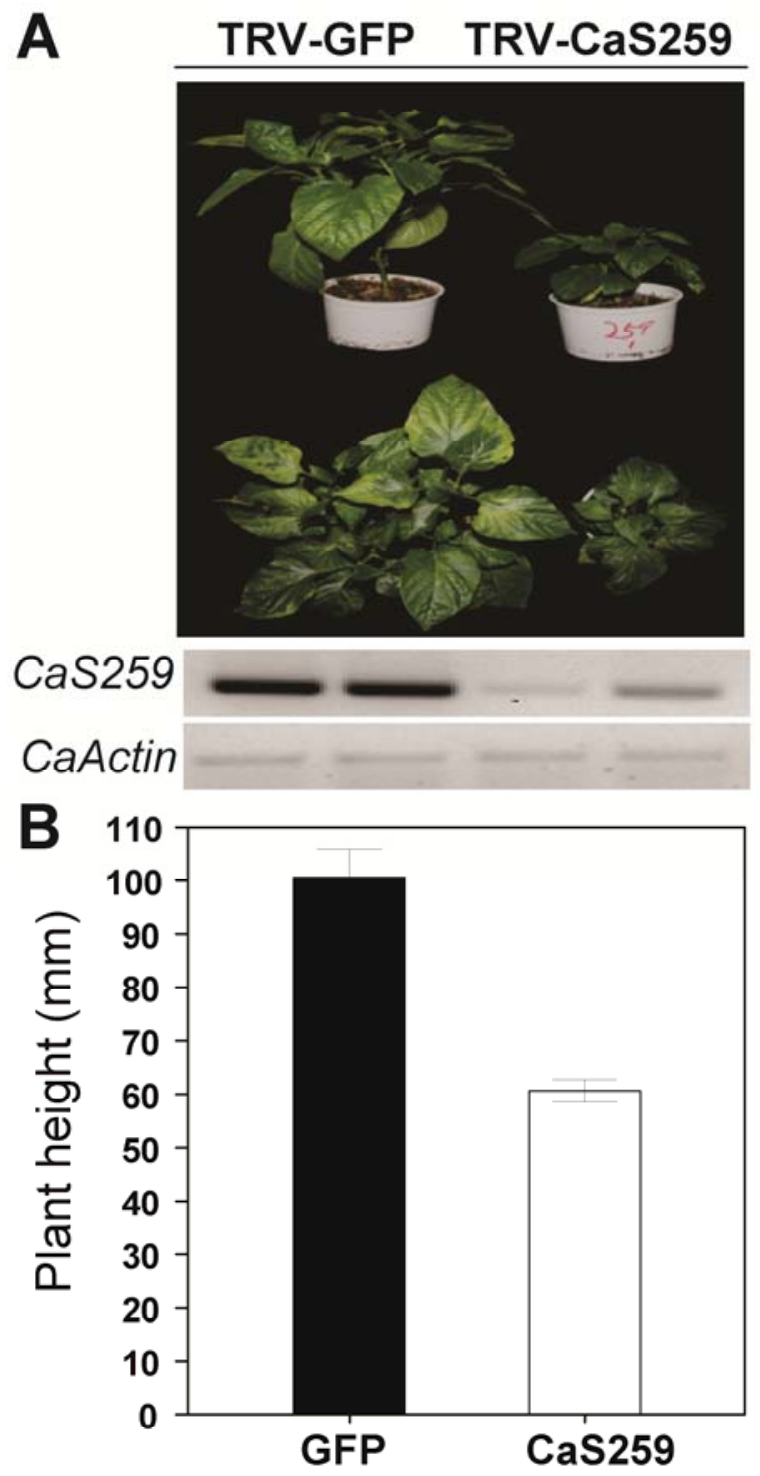

The CaS259 protein showed a high degree of similarity to PR4 (Supplementary Fig. S2). The PR4 family has been known to have potent antifungal and antimicrobial activity in vitro against a wide range of pathogens (Fiocchetti et al. 2008; Li et al. 2010; Zhu et al. 2006). This family of proteins is also modulated by pathogen infection, as well as by defense-signaling molecules (Bertini et al. 2003; Park et al. 2001). Expression of PR4 has also been known to be developmentally controlled in an organ-specific manner in healthy pepper (Park et al. 2001). Recently, PR4 proteins from various plants have been described as having RNase or DNase activity (Caporale et al. 2004; GuevaraMorato et al. 2010; Li et al. 2010), much of which is secreted to the apoplast, resulting in the breakdown of DNA and RNA and consequent HR cell death (Mittler and Lam 1997). In addition,
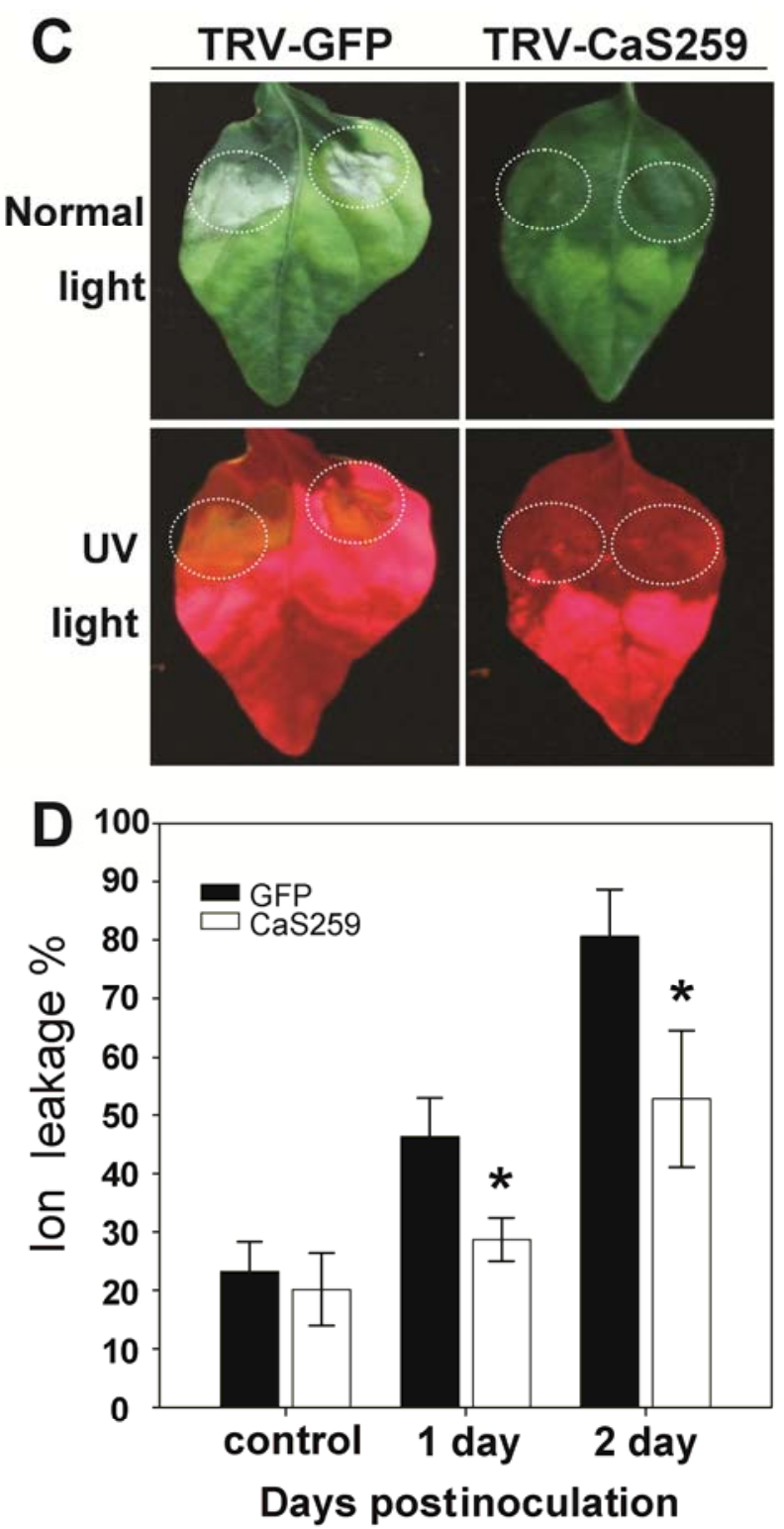

Fig. 5. Effects of Capsicum annuum secretome (CaS)259 silencing in pepper. A, Phenotype of CaS259-silenced pepper plants (upper panel). The picture was taken at 6 weeks after silencing. Semi-quantitative reverse-transcription polymerase chain reaction analysis for expression analysis of CaS259 gene in Tobacco rattle virus (TRV)- $\Delta$ green fluorescent protein (GFP) and TRV-CaS259 (N-terminal) infiltrated pepper. The level of actin was used as control (lower panel). B, Plant height of CaS259-silenced plants represented as comparison of plant height. The plant height was measured at 3 weeks after the onset of virus-induced gene silencing. In total, 15 plants were measured and data are indicated as means \pm standard deviation. Similar results were obtained from three independent experiments. C, Cell death of CaS259-silenced pepper plants following non-host pathogen (Xanthomonas axonopodis pv. glycines 8ra) inoculation. Xanthomonas axonopodis pv. glycines 8ra was infiltrated as $1 \times 10^{8} \mathrm{CFU} / \mathrm{ml}$ (optical density at $600 \mathrm{~nm}=0.1$ ). The picture was taken at 2 dpi under normal and UV light. D, Cell death by X. axonopodis pv. glycines 8ra (as in C) was quantified by measuring the ion leakage of inoculated regions. Data represent means of six leaf discs $(1 \mathrm{~cm}$ in diameter) and error bars represent standard deviations. The experiments were repeated three times with similar results. Asterisks indicate difference of significant level as determined by Student's $t$ test $(P<0.05)$. 
Guevara-Morato and associates (2010) suggested that the nuclease activity of $C$. chinense PR4 might contribute to the depletion of RNA and DNA fragments during cell death, as in programmed cell death and necrosis.

However, the roles of plant PR4 proteins in relation to cell death and development have not yet been elucidated. The nuclease function of PR4 can reasonably explain cell death delay in CaS259-silenced pepper following inoculation with Pseudomonas syringae pv. tomato $\mathrm{T} 1$ and $X$. axonopodis pv. glycines 8ra (Figs. 4 and 5C) or with Phytophthora capsici (Figs. 6A and 7A). To our knowledge, this is the first report showing that CaS259, a CaPR4-like protein, plays an essential role in the regulation of development and the cell death that can result from pathogen infection (Figs. 5, 6, and 7). These observations provide evidence that $\mathrm{CaS}$ genes play an important role in pathogen defense as well as plant development.

Our data strongly suggest that studies using these secreted proteins might contribute to understanding the fundamental basis of plant innate immunity that occurs at the interface of pathogen and host cell. Further investigations into the role of each gene could provide insights into some of the unknown functions of the plant secretome in pathogen defense and normal growth and development.

\section{MATERIALS AND METHODS}

\section{Plant materials.}

C. annuum CM334 (resistant to $P$. capsici) and C. annuum Chilsungcho (susceptible to $P$. capsici) were used for $P$. capsici infection experiments. C. annuum 'Bukang' was used for VIGS experiments and followed by bacterial pathogen infection. All plants were grown in a growth chamber at $25^{\circ} \mathrm{C}$ under a cycle of 16 and $8 \mathrm{~h}$ of light and darkness, respectively, and transported in a Magenta box $\left(7.2\right.$ by 7.2 by $10 \mathrm{~cm}^{3}$; SPL Life Science, Gyeonggi-do, Korea) for $P$. capsici infection (Kim et al. 2008).

\section{Pathogen preparation and inoculation.}

Preparation of $P$. capsici inocula was described previously (Kim et al. 2008). P. capsici Leon, 'Pa23', was grown in $3.9 \%$

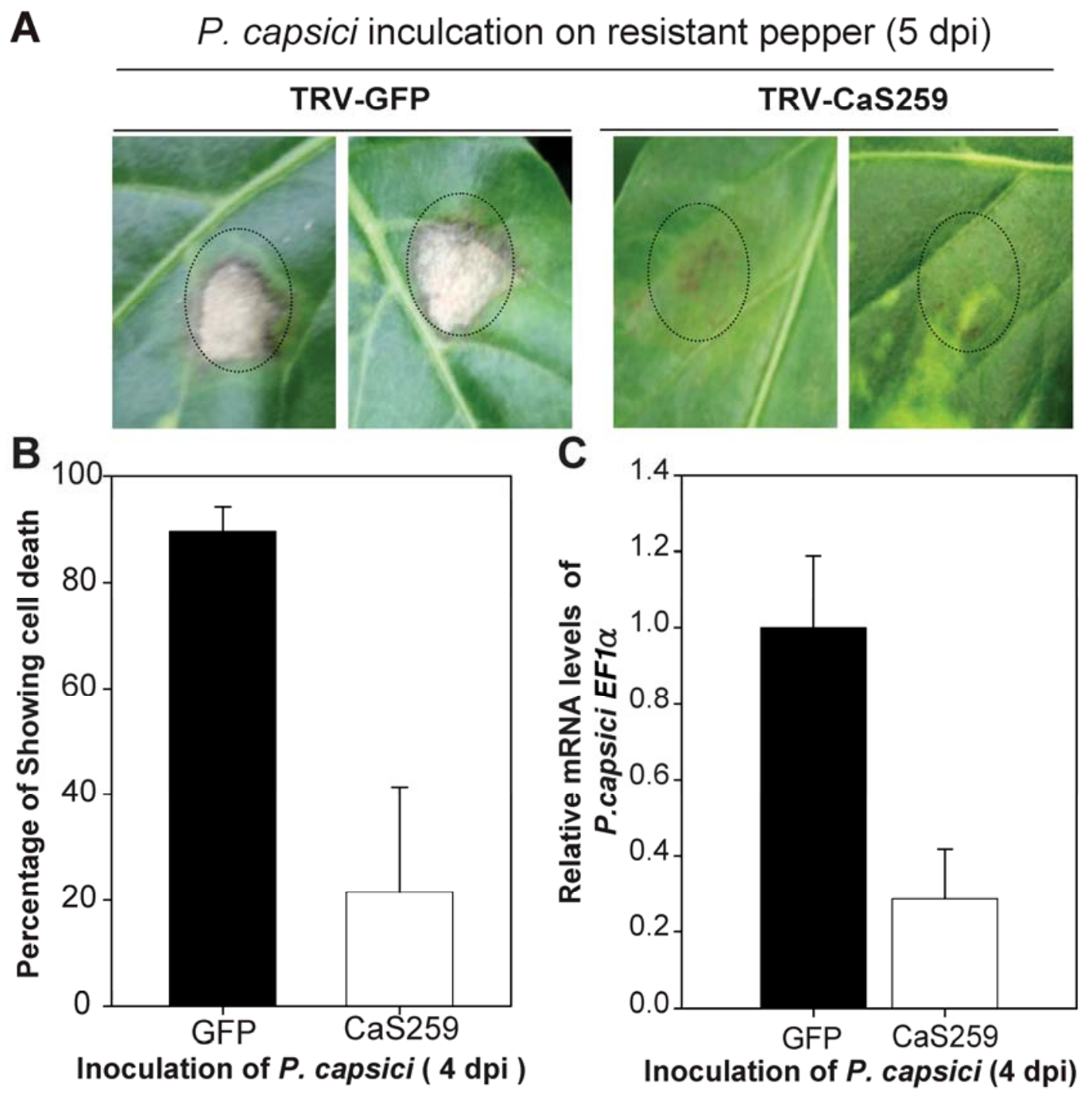

Fig. 6. Effects of Capsicum annuum secretome (CaS)259 gene silencing following Phytophthora capsici infection in resistant pepper. A, CaS259-silenced 'CM334' pepper was infiltrated on leaves by P. capsici as $2 \times 10^{5}$ zoospores $/ \mathrm{ml}$. The picture was taken at 5 days postinoculation (dpi). B, Percentages of sites showing cell death following $P$. capsici infection of leaves of CaS259-silenced CM334. In total, 10 leaves per line, comprising two leaves from five independent plants, were scored at 4 dpi. Data points represent the means \pm standard deviation. Similar results were obtained from three independent experiments. One representative experiment is shown. C, Quantitative reverse-transcription polymerase chain reaction of $P$. capsici colonization levels in CaS259-silenced CM334 and control pepper cultivars. Total RNA was extracted from P. capsici-infected regions at 4 dpi. Expression of the P. capsici Ef1 $\alpha$ (PcEfl $\alpha$ ) gene was normalized to the expression of CaActin. Values were calculated with biological three replications as standard deviations. 
potato dextrose agar medium for 7 days $\left(27^{\circ} \mathrm{C}\right.$, in the dark)and mycelial plugs $(8 \mathrm{~mm}$ in diameter) were cut from the periphery and cultured on V8 juice agar media (20\% V8 juice, $0.4 \% \mathrm{CaCO}_{3}$, and $1.8 \%$ agar) for 5 days. The mycelia were scraped and incubated under light for 2 days to promote sporangium formation. The plate was flooded with sterile water and incubated at $4^{\circ} \mathrm{C}$ for 1 to $2 \mathrm{~h}$; then, plates were placed at $28^{\circ} \mathrm{C}$ for $30 \mathrm{~min}$. The released zoospores were counted by

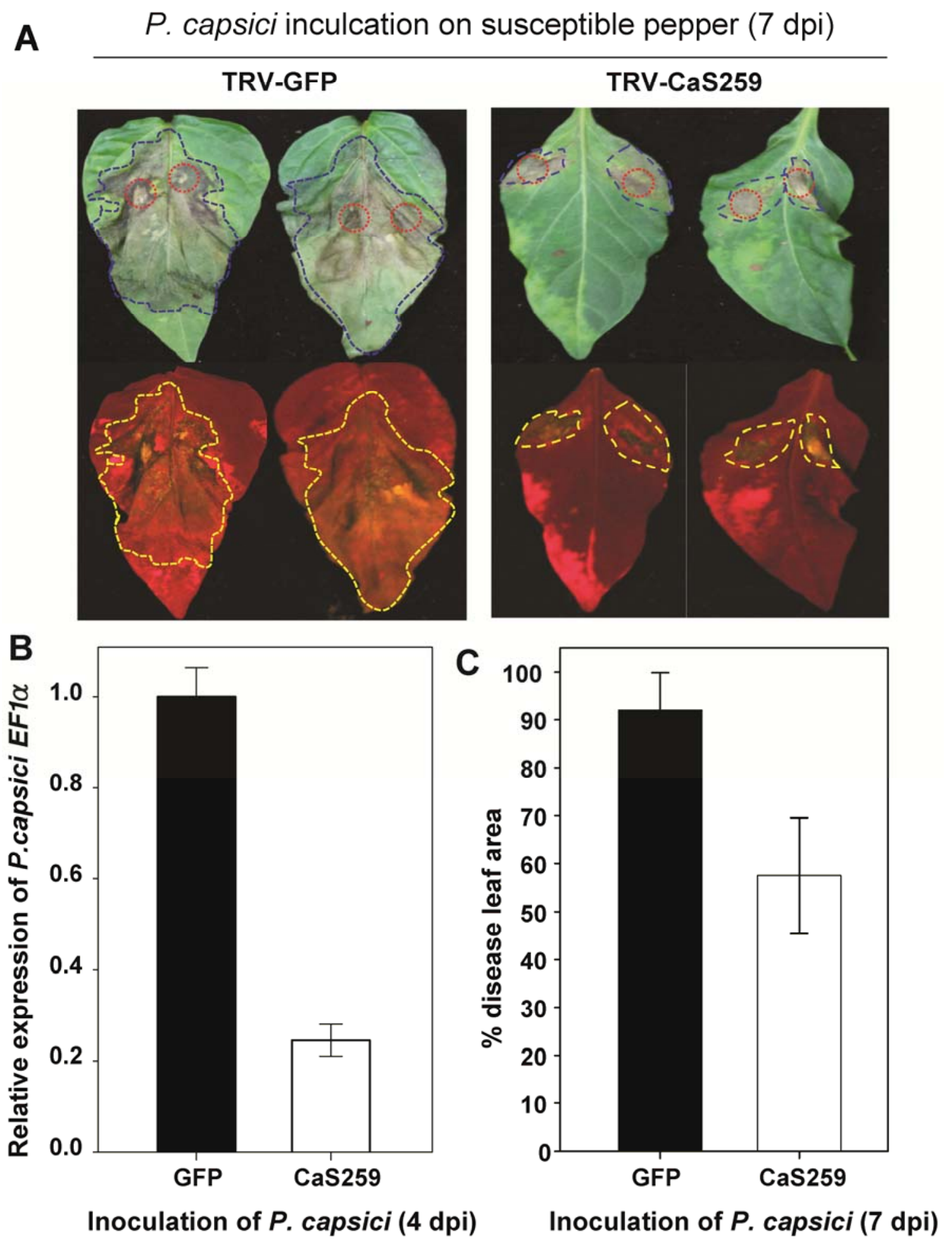

Fig. 7. Effects of Capsicum annuum secretome (CaS)259 gene silencing following Phytophthora capsici infection in susceptible pepper A, Disease symptom development on the leaves after P. capsici inoculation $\left(2 \times 10^{5}\right.$ zoospore $/ \mathrm{ml}$ ). The picture was taken at 7 days postinoculation (dpi) under normal (upper panel) and UV light (lower panel). Red circles indicate the site of $P$. capsici inoculation. Colored dotted lines (blue or yellow) indicate disease symptoms. B, $P$. capsici colonization in CaS259-silenced susceptible pepper was assessed by quantitative reverse-transcription polymerase chain reaction of the $P$. capsici $E f l \alpha(P c E f l \alpha)$ gene. Total RNA was extracted from P. capsici-infected leaves at 4 dpi. Expression of PcEfl $\alpha$ gene was normalized to the expression of CaActin. Values were calculated with biological three replications as standard deviations. C, Leaf area covered with Phytophthora blight lesion (\%) in CaS259-silenced pepper and control (Tobacco rattle virus [TRV]-green fluorescent protein [GFP]-infiltrated pepper) after inoculation with P. capsici. Data points represent the means \pm standard deviation from disease symptoms of 20 leaves (TRV-GFP) and 32 leaves (TRV-CaS259). Similar results were obtained from two independent experiments. One representative result is shown. 
hemacytometer and the concentration adjusted to $2 \times 10^{6}$ zoospores $/ \mathrm{ml}$ with sterile water.

Five-week-old pepper plants were inoculated with $P$. capsici zoospores. For root inoculation, $10 \mathrm{ml}$ of $10^{6}$ zoospores $/ \mathrm{ml}$ (final concentration $2 \times 10^{5}$ ) was introduced into the Magenta box. Growth conditions were maintained at $27^{\circ} \mathrm{C}$ with cycles of 16 and $8 \mathrm{~h}$ of light and darkness, respectively. $P$. capsiciinfected pepper roots were collected at $0,3,6,12,24,48$, and 72 hpi. Pseudomonas syringae pv. tomato T1 and X. axonopodis pv. glycines 8ra were grown overnight in liquid Luria-Bertani (LB) medium. The bacterial cultures resuspended in 10 $\mathrm{mM} \mathrm{MgCl}{ }_{2}$ were introduced into pepper leaves by pressure infiltration using a needless syringe (Oh et al. 2008; Yi et al. 2009).

\section{TTC reduction assay.}

The TTC reduction assay was modified from the methods of Chen and associates (2006). P. capsici-infected roots from each time point, including noninfected roots, were washed with sterile water for $10 \mathrm{~min}$ before TTC tests. Fresh roots (each $300 \mathrm{mg}$ ) were incubated with $5 \mathrm{ml}$ of $0.6 \%$ TTC (SigmaAldrich, St. Louis) in $50 \mathrm{mM}$ phosphate buffer ( $\mathrm{pH} 7.4$ ) for 22 $\mathrm{h}$ at $30^{\circ} \mathrm{C}$ in the dark. Roots were then washed twice with sterile water. Formazan (reduced TTC) was extracted twice from the roots with $95 \% \mathrm{EtOH}$ at $80^{\circ} \mathrm{C}$ for $30 \mathrm{~min}$. Combined extracts were adjusted to a final volume of $15 \mathrm{ml}$ and absorbance was read at $490 \mathrm{~nm}$ (model DU 730; Beckman Coulter, Fullerton, CA, U.S.A.). Assays were performed three times in each independent experiment.

\section{Construction of YST cDNA library.}

Isolation of total RNAs from resistant and susceptible pepper roots following Phytophthora capsici infection were performed by the method of Choi and associates (1996) and mRNAs from resistant pepper roots were purified by the oligotex mRNA minikit (Qiagen, Chatsworth, CA, U.S.A.). The pYST vector system used for library construction was as previously described (Lee et al. 2006b). The HybriZAP cDNA synthesis kit (Stratagene, La Jolla, CA, U.S.A.) was used for random-primed cDNA synthesis and a random primer $\left(5^{\prime}-\mathrm{GA}\right.$ GAGAGAGAGAGAGACCGCGGCCGCCGCCNNNNNN-3'), including a NotI restriction enzyme site (underlined), was used for first-strand synthesis. After second-strand synthesis, ligation with an EcoRI adaptor, 5'-end phosphorylation with T4 polynucleotide kinase, digestion with NotI, and cDNA sizefractionation was performed using the approximately 300- to 1,000-bp gel elution fraction. The cDNAs were ligated to an equimolecular mixture of the EcoRI- and NotI-digested pYST 0,1 , and 2 vectors. TOP10 electrocompetent cells (Invitrogen, Carlsbad, CA, U.S.A.) were used for transformation of the ligation mixture. After transformation, the cells were plated on LB agar plates including ampicillin at $50 \mathrm{mg} / \mathrm{ml}$. Plasmid DNA was isolated from a pooled sample of the transformants (YST library) using the Perfect prep plasmid midi kit (Eppendorf, Hamburg, Germany).

\section{Yeast transformation, selection, and sequencing.}

YST library plasmids were transformed into an invertase-deficient yeast mutant strain, DBY $\alpha 2445$ (Saccharomyces cerevisiae, MAT $\alpha$, suc2 -9 , lys2-801, ura3-52, ade2-101) by the YEASTMAKER Yeast Transformation System2 (BD Bioscience, San Jose, CA, U.S.A.). Transformants were selected on YP-Suc medium (1\% Bacto yeast extract, 2\% Bacto peptone, and $2 \%$ agar), and incubated at $30^{\circ} \mathrm{C}$ for 8 to 9 days. Colonies were restreaked on an YP-Suc medium. After incubation at $30^{\circ} \mathrm{C}$ for 2 days, plasmids were isolated from the yeast colonies. The cDNAs selected from the first screen were used for identifying redundant clones using Southern blot assay, in an iterative step. The plasmids were then transformed into $\mathrm{DH} 10 \mathrm{~b}$ Escherichia coli electrocompetent cells, and the isolated plasmids were sequenced using the ADH1 primer (5'-TCCTCGTC ATTGTTCTCGTTCC-3') (Lee et al. 2006b). All rescued plasmids from $E$. coli were retransformed into yeast to reconfirm the ability to grow on sucrose selection medium at least twice. YST clones were sequenced (NICEM, Korea) and sequence similarity was determined using the National Center for Biotechnology Information and Phytophthora Functional Genomics Database. To identify the gene annotation, the sequences of the $\mathrm{CaS}$ clones were compared with pepper expressed sequence tag databases (Gene Pool and Sol Genomic Network). DNA sequences were translated into amino acid sequence using the ExPasy translation tool (Appel et al. 1994). Signal peptides were predicted by the SignalP3.0 program (Bendtsen et al. 2004) and subcellular localization was predicted using the TargetP (Emanuelsson et al. 2000) and PSORT programs (Nakai and Horton 1999).

\section{Northern blot analysis.}

Total RNA $(10 \mu \mathrm{g})$ was electrophoresed on $1.2 \%$ formaldehyde agarose gels and blotted onto Hybond- $\mathrm{N}^{+}$membranes (Amersham Biosciences, Piscataway, NJ, U.S.A.). The membranes were hybridized with $\left[\alpha{ }^{32} \mathrm{P}\right]$-labeled partial cDNA fragments of YST clones at $65^{\circ} \mathrm{C}$ overnight. After hybridization, the membranes were washed with $2 \times \mathrm{SSC}(1 \times \mathrm{SSC}$ is $0.15 \mathrm{M} \mathrm{NaCl}$ plus $0.015 \mathrm{M}$ sodium citrate) $(\mathrm{pH} 7.2)$ and $0.1 \%$ sodium dodecyl sulfate (SDS) at $65^{\circ} \mathrm{C}$ for $15 \mathrm{~min}$, with $1 \times$ SSC and $0.1 \%$ SDS at $65^{\circ} \mathrm{C}$ for $15 \mathrm{~min}$, and with $0.5 \times \mathrm{SSC}$ and $0.1 \% \mathrm{SDS}$ at $65^{\circ} \mathrm{C}$ for $15 \mathrm{~min}$. Membranes were exposed to X-ray film at $-80^{\circ} \mathrm{C}$ for 3 to $24 \mathrm{~h}$.

\section{Dot-blot assay.}

Approximately $2 \mu \mathrm{g}$ of pYST plasmid DNA containing cDNA-encoding signal peptide (containing approximately 100 ng of each cDNA) was used for reverse Northern blotting. Dot-blot hybridization was performed using the Bio-Dot SF microfiltration apparatus (Bio-Rad, Hercules, CA, U.S.A.) following the manufacturer's protocol, with slight modification. Fourteen RNA probes were generated: time course RNA (0, 3, $6,12,24,48$, and $72 \mathrm{~h}$ ) from resistant and susceptible pepper roots after $P$. capsici infection. Total RNA (5 $\mu$ g each sample) was used for template cDNA synthesis using the SUPERSCRIPT II RNase-Reverse-Transcriptase system (Invitrogen) in a mixture with anchor primer (oligo-dT), dNTP mixture minus dCTP, and $\left[\alpha-{ }^{32} \mathrm{P}\right]-\mathrm{dCTP}(3,000 \mathrm{Ci} / \mathrm{mmol})$ (Amersham Biosciences). The labeled probes were separated from unincorporated nucleotides using mini-Quick Spin DNA columns (Roche Applied Science, Mannheim, Germany). Membranes were prehybridized at $65^{\circ} \mathrm{C}$ for $3 \mathrm{~h}$ in hybridization buffer $(0.5$ M sodium phosphate [pH 7.2], 7\% SDS, 1 mM EDTA). Labeled cDNA probe was mixed with fresh buffer and hybridized at $65^{\circ} \mathrm{C}$ for at least $16 \mathrm{~h}$. After hybridization, blots were washed twice in $2 \times \mathrm{SSC}$ and $0.1 \% \mathrm{SDS}$ at $65^{\circ} \mathrm{C}$ for $5 \mathrm{~min}$, once in $1 \times \mathrm{SSC}$ and $0.1 \% \mathrm{SDS}$ at $65^{\circ} \mathrm{C}$ for $15 \mathrm{~min}$, and twice $0.1 \times \mathrm{SSC}$ and $0.1 \% \mathrm{SDS}$ at $65^{\circ} \mathrm{C}$ for $10 \mathrm{~min}$. The washed membranes were exposed to a BAS imaging plate (Fujifilm, Tokyo) and quantified by scanning the plate with a Fujix BAS2500 (Fujifilm).

\section{qRT-PCR.}

For qRT-PCR, total RNA ( $5 \mu \mathrm{g}$ ) was reverse-transcribed using the SUPERSCRIPT II RNase-Reverse-Transcriptase system (Invitrogen). Triplicate samples were analyzed using a RotorGene 6000 apparatus (Qiagen) with SYBR Green (Invitrogen), according to the manufacturer's instructions. The relative quan- 
titation of gene expression was calculated by the relative standard curve method (Larionov et al. 2005). The CaActin gene was used to normalize expression levels, and noninoculated pepper plants were used as controls for expression of the target genes (Supplementary Table S2). Expression levels were reported as mean values with standard errors.

\section{Construction of the TRV-CaS vector and VIGS in pepper.}

$\mathrm{CaS}$ genes in the pYST vector were digested with EcoRI and KpnI and cloned into a TRV-based gene silencing vector (pTRV2) via the same enzyme sites. Average insert size was approximately 370 nucleotides. The pTRV2 vectors containing $\mathrm{CaS}$ genes were transformed into Agrobacterium sp. strain GV2260 by the freeze-thaw method (An 1987) and the TRVbased VIGS on pepper was performed as described by Chung and associates (2004).

\section{Measurement of ion leakage.}

The measurement of ion leakage was performed as described by Lee and associates (2010). Two days after inoculation with bacterial pathogen, three leaf discs (1 cm in diameter) were floated on $5 \mathrm{ml}$ of distilled water for $2 \mathrm{~h}$ at room temperature. Electrical conductivity was measured using a conductivity meter (model 455C; Istek, Seoul). To release whole electrolytes from leaf discs, samples were autoclaved, cooled to room temperature, and measured with a conductivity meter. Ion leakage was expressed as percent leakage to conductivity of control sample.

\section{ACKNOWLEDGMENTS}

This work was supported by a grant from the Crop Functional Genomic Center (CG1132) and the National Research Foundation (project number 2010-0015105) of MEST of Korean Government. S.-I. Yeom is a scholarship grantee (S2_2009_000_0210_1) from the Korea Student Aid Foundation (KOSAF). J. Rose was supported by a grant from the National Science Foundation (NSF) Plant Genome program (DBI-0606595). B.-D. Kim and D. Choi contributed equally as corresponding authors.

\section{LITERATURE CITED}

An, G. 1987. Binary Ti-vectors for plant transformation and promoter analysis. Methods Enzymol. 153:292-305.

Appel, R., Bairoch, A., and Hochstrasser, D. 1994. A new generation of information retrieval tools for biologists: The example of the ExPASy WWW server. Trends Biochem. Sci. 19:258-260.

Bendtsen, J., Nielsen, H., Von Heijne, G., and Brunak, S. 2004. Improved prediction of signal peptides: SignalP3.0. J. Mol. Biol. 340:783-759.

Bernhardt, C., and Tierney, M. L. 2000. Expression of AtPRP3, a prolinerich structural cell wall protein from Arabidopsis, is regulated by celltype-specific developmental pathways involved in root hair formation. Plant Physiol. 122:705-714.

Bertini, L., Leonardi, L., Caporale, C., Tucci, M., Cascone, N., Di Berardino, I., Buonocore, V., and Caruso, C. 2003. Pathogen-responsive wheat PR4 genes are induced by activators of systemic acquired resistance and wounding. Plant Sci. 164:1067-1078.

Birch, P. R., Rehmany, A. P., Pritchard, L., Kamoun, S., and Beynon, J. L. 2006. Trafficking arms: Oomycete effectors enter host plant cells. Trends Microbiol. 14:8-11.

Caporale, C., Di Berardino, I., Leonardi, L., Bertini, L., Cascone, A. Buonocore, V., and Caruso, C. 2004. Wheat pathogenesis-related proteins of class 4 have ribonuclease activity. FEBS (Fed. Eur. Biochem. Soc.) Lett. 575:71-76.

Cecchetti, V., Altamura, M. M., Serino, G., Pomponi, M., Falasca, G., Costantino, P., and Cardarelli, M. 2007. ROX1, a gene induced by rolB, is involved in procambial cell proliferation and xylem differentiation in tobacco stamen. Plant J. 49:27-37.

Chen, C. W., Yang, Y. W., Lur, H. S., Tsai, Y. G., and Chang, M. C. 2006. A novel function of abscisic acid in the regulation of rice (Oryza sativa L.) root growth and development. Plant Cell Physiol. 47:1-13.

Choi, D., Kim, H., Yun, H., Park, J., Kim, W., and Bok, S. 1996. Molecular cloning of a metallothionein-like gene from Nicotiana glutinosa L. and its induction by wounding and tobacco mosaic virus infection. Plant
Physiol. 112:353-359.

Chung, E., Seong, E., Kim, Y. C., Chung, E. J., Oh, S. K., Lee, S., Park, J. M., Joung, Y. H., and Choi, D. 2004. A method of high frequency virusinduced gene silencing in chili pepper (Capsicum annиum L. cv. Bukang). Mol. Cells 17:377-380.

Cutler, S. R., Ehrhardt, D. W., Griffitts, J. S., and Somerville, C. R. 2000. Random GFP::cDNA fusions enable visualization of subcellular structures in cells of Arabidopsis at a high frequency. Proc. Natl. Acad. Sci. U.S.A. 97:3718-3723.

Dong, Y., Burch-Smith, T. M., Liu, Y., Mamillapalli, P., and Dinesh-Kumar, S. P. 2007. A ligation-independent cloning tobacco rattle virus vector for high-throughput virus-induced gene silencing identifies roles for NbMADS4-1 and -2 in floral development. Plant Physiol. 145:1161-1170.

Dunaevskii Ia, E., Elpidina, E. N., Vinokurov, K. S., and Belozerskii, M. A. 2005. Protease inhibitors: Use to increase plant tolerance to insects and pathogens. Mol. Biol. (Moscow) 39:702-708.

Emanuelsson, O., Nielsen, H., Brunak, S., and von Heijne, G. 2000. Predicting subcellular localization of proteins based on their N-terminal amino acid sequence. J. Mol. Biol. 300:1005-1016.

Emanuelsson, O., Brunak, S., von Heijne, G., and Nielsen, H. 2007. Locating proteins in the cell using TargetP, SignalP and related tools. Nat. Protocols 2:953.

Fiocchetti, F., D'Amore, R., De Palma, M., Bertini, L., Caruso, C., Caporale, C., Testa, A., Cristinzio, G., Saccardo, F., and Tucci, M. 2008. Constitutive over-expression of two wheat pathogenesis-related genes enhances resistance of tobacco plants to Phytophthora nicotianae. Plant Cell Tissue Organ Cult. 92:73-84.

Fowler, T. J., Bernhardt, C., and Tierney, M. L. 1999. Characterization and expression of four proline-rich cell wall protein genes in Arabidopsis encoding two distinct subsets of multiple domain proteins. Plant Physiol. 121:1081-1091.

Goo, J. H., Park, A. R., Park, W. J., and Park, O. K. 1999. Selection of Arabidopsis genes encoding secreted and plasma membrane proteins Plant Mol. Biol. 41:415-423.

Guevara-Morato, M. A., Garcia de Lacoba, M., Garcia-Luque, I., and Serra, M. T. 2010. Characterization of a pathogenesis-related protein 4 (PR-4) induced in Capsicum chinense L3 plants with dual RNase and DNase activities. J. Exp. Bot. 61:3259-3271.

Hausbeck, M. K., and Lamour, K. H. 2004. Phytophthora capsici on vegetable crops: Research progress and management challenges. Plant Dis 88:1292-1303.

Hematy, K., Cherk, C., and Somerville, S. 2009. Host-pathogen warfare at the plant cell wall. Curr. Opin. Plant Biol. 12:406-413.

Hong, J. K., and Hwang, B. K. 2002. Induction by pathogen, salt and drought of a basic class II chitinase mRNA and its in situ localization in pepper (Capsicum annuum). Physiol. Plant. 114:549-558.

Hugot, K., Riviere, M. P., Moreilhon, C., Dayem, M. A., Cozzitorto, J. Arbiol, G., Barbry, P., Weiss, C., and Galiana, E. 2004. Coordinated regulation of genes for secretion in tobacco at late developmental stages: Association with resistance against oomycetes. Plant Physiol. 134:858-870

Hwang, B. K., Kim, W. B., and Kim, W. K. 1989. Ultrastructure at the host-parasite interface of Phytophthora capsici in roots and stems of Capsicum annuum. J. Phytopathol. 127:305-315.

Ilarslan, H., Ustun, A. S., and Yilmazer, R. 1996. Ultrastructural changes in crowns of peppers resistant and susceptible to Phytophthora capsici. J. Turk Phytopathol. 25:11-22.

Jacobs, K. A., Collins-Racie, L. A., Colbert, M., Duckett, M., GoldenFleet, M., Kelleher, K., Kriz, R., LaVallie, E. R., Merberg, D., Spaulding, V., Stover, J., Williamson, M. J., and McCoy, J. M. 1997. A genetic selection for isolating cDNAs encoding secreted proteins. Gene 198:289-296.

Jones, D. A., and Takemoto, D. 2004. Plant innate immunity - direct and indirect recognition of general and specific pathogen-associated molecules. Curr. Opin. Immunol. 16:48-62.

Kamoun, S. 2006. A catalogue of the effector secretome of plant pathogenic oomycetes. Annu. Rev. Phytopathol. 44:41-60.

Kim, H. J., Nahm, S. H., Lee, H. R., Yoon, G. B., Kim, K. T., Kang, B. C., Choi, D., Kweon, O. Y., Cho, M. C., Kwon, J. K., Han, J. H., Kim, J. H., Park, M., Ahn, J. H., Choi, S. H., Her, N. H., Sung, J. H., and Kim, B. D. 2008. BAC-derived markers converted from RFLP linked to Phytophthora capsici resistance in pepper (Capsicum annuum L.). Theor. Appl. Genet. 118:15-27.

Kim, Y. S., Park, J. Y., Kim, K. S., Ko, M. K., Cheong, S. J., and Oh, B. J. 2002. A thaumatin-like gene in nonclimacteric pepper fruits used as molecular marker in probing disease resistance, ripening, and sugar accumulation. Plant Mol. Biol. 49:125-135.

Klein, R. D., Gu, Q., Goddard, A., and Rosenthal, A. 1996. Selection for genes encoding secreted proteins and receptors. Proc. Natl. Acad. Sci. U.S.A. 93:7108-7113. 
Larionov, A., Krause, A., and Miller, W. 2005. A standard curve based method for relative real time PCR data processing. BMC Bioinf. 6:62.

Lee, S. J., Saravanan, R. S., Damasceno, C. M., Yamane, H., Kim, B. D. and Rose, J. K. 2004. Digging deeper into the plant cell wall proteome. Plant Physiol. Biochem. 42:979-988.

Lee, S. J., Kelley, B. S., Damasceno, C. M., St. John, B., Kim, B. S., Kim, B. D., and Rose, J. K. 2006a. A functional screen to characterize the secretomes of eukaryotic pathogens and their hosts in planta. Mol. Plant-Microbe Interact 19:1368-1377.

Lee, S.-J., Kim, B.-D., and Rose, J. K. C. 2006b. Identification of eukaryotic secreted and cell surface proteins using the yeast secretion trap screen. Nat. Protocols 1:2439.

Lee, Y. K., Hong, J. K., Hippe-Sanwald, S., and Hwang, B. K. 2000. Histological and ultrastructural comparisons of compatible, incompatible and DL-beta-amino-n-butyric acid-induced resistance responses of pepper stems to Phytophthora capsici. Physiol. Mol. Plant Pathol. 57:269-280.

Lefebvre, V., and Palloix, A. 1996. Both epistatic and additive effects of QTLs are involved in polygenic induced resistance to disease: A case study, the interaction pepper-Phytophthora capsici Leonian. Theor. Appl. Genet. 93:503-511.

Li, X. D., Xia, B., Jiang, Y. M., Wu, Q. S., Wang, C. Y., He, L. S., Peng, F. and Wang, R. 2010. A new pathogenesis-related protein, LrPR4, from Lycoris radiata, and its antifungal activity against Magnaporthe grisea. Mol. Biol. Rep. 37:995-1001.

Liu, Y. L., Schiff, M., and Dinesh-Kumar, S. P. 2002. Virus-induced gene silencing in tomato. Plant J. 31:777-786.

Liu, Y. L., Schiff, M., and Dinesh-Kumar, S. P. 2004. Involvement of MEK1 MAPKK, NTF6 MAPK, WRKY/MYB transcription factors, COI1 and CTR1 in N-mediated resistance to Tobacco mosaic virus. Plant J. 38:800-809.

Mithofer, A., Muller, B., Wanner, G., and Eichacker, L. A. 2002. Identification of defence-related cell wall proteins in Phytophthora sojaeinfected soybean roots by ESI-MS/MS. Mol. Plant Pathol. 3:163-166.

Mittler, R., and Lam, E. 1997. Characterization of nuclease activities and DNA fragmentation induced upon hypersensitive response cell death and mechanical stress. Plant Mol. Biol. 34:209-221.

Moy, P., Qutob, D., Chapman, B. P., Atkinson, I., and Gijzen, M. 2004. Patterns of gene expression upon infection of soybean plants by Phytophthora sojae. Mol. Plant-Microbe Interact. 17:1051-1062.

Nakai, K., and Horton, P. 1999. PSORT: A program for detecting sorting signals in proteins and predicting their subcellular localization. Trends Biochem. Sci. 24:34-36.

Nakai, K., and Kanehisa, M. 1992. A knowledge base for predicting protein localization sites in eukaryotic cells. Genomics 14:897-911.

Niebel, A., de Almeida Engler, J., Tire, C., Engler, G., Van Montagu, M., and Gheysen, G. 1993. Induction patterns of an extensin gene in tobacco upon nematode infection. Plant Cell 5:1697.

Oelke, L. M., Bosland, P. W., and Steiner, R. 2003. Differentiation of race specific resistance to Phytophthora root rot and foliar blight in Capsicum anпиит. J. Am. Soc. Hortic. Sci. 128:213-218.

Oh, B. J., Ko, M. K., Kostenyuk, I., Shin, B., and Kim, K. S. 1999. Coexpression of a defensin gene and a thionin-like via different signal transduction pathways in pepper and Colletotrichum gloeosporioides interactions. Plant Mol. Biol. 41:313-319.

Oh, I. S., Park, A. R., Bae, M. S., Kwon, S. J., Kim, Y. S., Lee, J. E., Kang, N. Y., Lee, S., Cheong, H., and Park, O. K. 2005. Secretome analysis reveals an Arabidopsis lipase involved in defense against Alternaria brassicicola. Plant Cell 17:2832-2847.

Oh, S. K., Bek, K. H., Park, J. M., Yi, S. Y., Yu, S. H., Kamoun, S., and Choi, D. 2008. Capsicum annuum WRKY protein CaWRKY1 is a negative regulator of pathogen defense. New Phytol. 177:977-989.

Park, C. J., Shin, R., Park, J. M., Lee, G. J., Yoo, T. H., and Paek, K. H. 2001. A hot pepper cDNA encoding a pathogenesis-related protein 4 is induced during the resistance response to Tobacco mosaic virus. Mol. Cells 11:122-127.

Park, C. J., An, J. M., Shin, Y. C., Kim, K. J., Lee, B. J., and Paek, K. H. 2004a. Molecular characterization of pepper germin-like protein as the novel PR-16 family of pathogenesis-related proteins isolated during the resistance response to viral and bacterial infection. Planta 219:797-806.

Park, C. J., Kim, K. J., Shin, R., Park, J. M., Shin, Y. C., and Paek, K. H. 2004b. Pathogenesis-related protein 10 isolated from hot pepper functions as a ribonuclease in an antiviral pathway. Plant J. 37:186-198.
Pelegrini, P. B., and Franco, O. L. 2005. Plant gamma-thionins: Novel insights on the mechanism of action of a multi-functional class of defense proteins. Int. J. Biochem. Cell Biol. 37:2239-2253.

Richins, R. D., Micheletto, S., and O'Connell, M. A. 2010. Gene expression profiles unique to chili (Capsicum annuum L.) resistant to Phytophthora root rot. Plant Sci. 178:192-201.

Ristaino, J. B., and Johnston, S. A. 1999. Ecologically based approaches to management of Phytophthora blight on bell pepper. Plant Dis. 83:10801089

Rose, J. K., and Lee, S. J. 2010. Straying off the highway: Trafficking of secreted plant proteins and complexity in the plant cell wall proteome. Plant Physiol. 153:433-436.

Schmelzer, E. 2002. Cell polarization, a crucial process in fungal defence. Trends Plant Sci. 7:411-415.

Schulze-Lefert, P. 2004. Knocking on heaven's wall: Pathogenesis of and resistance to biotrophic fungi at the cell wall. Curr. Opin. Plant Biol. 7:377-383.

Silvar, C. S., Merino, F., and Díaz, J. 2008. Differential activation of defense-related genes in susceptible and resistant pepper cultivars infected with Phytophthora capsici. J. Plant Physiol. 165:1120-1124.

Stinzi, A., Heitz, T., Prasad, V., Wiedeman-Merdinoglu, S., Kauffmann, S., and Geoffroy, P. 1993. Plant 'pathogenesis-related' proteins and their role in defense against pathogens. Biochimie 75:687-706.

Tashiro, K., Tada, H., Heilker, R., Shirozu, M., Nakano, T., and Honjo, T. 1993. Signal sequence trap: A cloning strategy for secreted proteins and type I membrane proteins. Science 261:600-603.

Thabuis, A., Palloix, A., Pflieger, S., Daubeze, A. M., Caranta, C., and Lefebvre, V. 2003. Comparative mapping of Phytophthora resistance loci in pepper germplasm: Evidence for conserved resistance loci across Solanaceae and for a large genetic diversity. Theor. Appl. Genet. 106:1473-1485.

Tyler, B. M. 2007. Phytophthora sojae: Root rot pathogen of soybean and model oomycete. Mol. Plant Pathol. 8:1-8.

Ueeda, M., Kubota, M., and Nishi, K. 2006. Contribution of jasmonic acid to resistance against Phytophthora blight in Capsicum annuum cv. SCM334. Physiol. Mol. Plant Pathol. 67:149-154.

van der Hoorn, R. A. L. 2008. Plant proteases: From phenotypes to molecular mechanisms. Annu. Rev. Plant Biol. 59:191-223.

van Loon, L. C., Rep, M., and Pieterse, C. M. 2006. Significance of inducible defense-related proteins in infected plants. Annu. Rev. Phytopathol. 44:135-162.

Walker, S. J., and Bosland, P. W. 1999. Inheritance of Phytophthora root rot and foliar blight resistance in pepper. J. Am. Soc. Hortic. Sci. 124:14-18.

Wang, D., Weaver, N. D., Kesarwani, M., and Dong, X. 2005. Induction of protein secretory pathway is required for systemic acquired resistance. Science 308:1036-1040.

Wei, G., and Shirsat, A. H. 2006. Extensin over-expression in Arabidopsis limits pathogen invasiveness. Mol. Plant Pathol. 7:579-592.

Yamane, H., Lee, S. J., Kim, B. D., Tao, R., and Rose, J. K. 2005. A coupled yeast signal sequence trap and transient plant expression strategy to identify genes encoding secreted proteins from peach pistils. J. Exp. Bot. 56:2229-2238

Yi, S. Y., Lee, D. J., Yeom, S. I., Yoon, J., Kim, Y. H., Kwon, S. Y., and Choi, D. 2009. A novel pepper (Capsicum апnиит) receptor-like kinase functions as a negative regulator of plant cell death via accumulation of superoxide anions. New Phytol. 185:701-715.

Zhu, T., Song, F., and Zheng, Z. 2006. Molecular characterization of the rice pathogenesis-related protein, OsPR- $4 \mathrm{~b}$, and its antifungal activity against Rhizoctonia solani. J. Phytopathol. 154:378-384.

\section{AUTHOR-RECOMMENDED INTERNET RESOURCES}

Center for Biological Sequence Analysis TargetP prediction server: www.cbs.dtu.dk/services/TargetP Gene Pool server: genepool.kribb.re.kr

National Center for Biotechnology Information: www.ncbi.nlm.nih.gov

Oomycete Genomic databse: www.oomycete.org/ogd

PSORT WWW server: psort.nibb.ac.jp

SignalP3.0 server: www.cbs.dtu.dk/services/SignalP

Sol Genomics Network website: sgn.cornell.edu 